Revista Geográfica Digital. IGUNNE. Facultad de Humanidades. UNNE. Año 11. № 22.

Julio - Diciembre 2014. ISSN 1668-5180 Resistencia, Chaco

\title{
Expansión Urbana, Parantrofitia y Parantrozootia... ¿Biocenosis Antropogénicas? El Caso del Área Metropolitana del Gran Resistencia (A.M.G.R.), Chaco.
}

\author{
Juan Antonio Alberto \\ Instituto de Geografía, Facultad de Humanidades. \\ Universidad Nacional del Nordeste \\ E-mail: jalberto@hum.unne.edu.ar
}

\section{RESUMEN}

Este escrito expone y resume fundamentos teóricos y valoraciones prácticas sobre el fenómeno de expansión urbana asociado a sus paisajes, impactos y problemas derivados, en este caso nos centramos en las fitocenosis y zoocenosis asociadas a los grupos humanos y sus actividades cotidianas, hechos referidos al Área Metropolitana del Gran Resistencia (AMGR), en la Provincia del Chaco, como parte del trabajo de investigación que se realiza en el Departamento e Instituto de Geografía, de la Facultad de Humanidades, UNNE.

Se analizan los principales ambientes y paisajes resultantes de la expansión urbana del A.M.G.R., en especial en el sector Norte, espacio periurbano con fuerte tendencia a la urbanización y rápidos cambios en los usos del suelo, determinando una fuerte dinámica entre lo natural y lo artificial, entre lo urbano y lo rural que suscitan distintas suertes de sucesiones ecológicas secundarias (ambientes ruderales, viarios o viales, arvenses y segetales) y espacios de disclimax, donde se borran las improntas de las fisonomías vegetales primigenias y aparece el dominio construido conformando espacios variables según usos y densidades de edificación, acompañados por una serie de comunidades vegetales y animales asociadas a los grupos humanos (parantrofitia y parantrozootia respectivamente), que imprimen nuevas fisonomías y dinámicas ambientales.

Todas estas mutaciones generan notables impactos ambientales y atentan contra los fundamentos del desarrollo urbano sostenible, ya sea por el dinamismo del fenómeno urbano, por especulaciones económicas, por políticas insuficientes o laxas y -en general- por desconocimiento y falta de una cultura ambiental en la comunidad toda.

Palabras Claves: Expansión urbana, impactos ambientales, fitocenosis, zoocenosis, ruderal, arvense, parantrofitia.

\section{ABSTRACT \\ Urban expansion, Parantrofitia and Parantrozootia... ¿Anthropogenic Biocenosis? The Case of the Metropolitan Area of Gran Resistencia (AMGR), Chaco.}

This paper presents and summarizes theoretical and practical assessments on the phenomenon of urban sprawl associated with its landscapes, impacts and issues arising in this case we focus on zoocoenosis and phytocoenoses associated with human groups and their daily activities, events concerning the area metropolitan of Gran Resistencia (AMGR) in Chaco, as part of the research work carried out in the Department and Institute of Geography, Faculty of Humanities, UNNE.

Major environments and landscapes resulting from urban expansion AMGR, especially in the northern sector, suburban space with strong trend towards urbanization and rapid changes in land use, determining a strong dynamic between the natural and the artificial are analyzed between urban and rural aroused different fates of secondary ecological succession (ruderal, roads, weeds and segetales environments) and disclimax spaces where the imprints of primordial plant physiognomies are erased and the space appears built spaces as variables conforming uses and building densities, accompanied by a number of plant and animal

Publicado en formato digital: Prof. Juan Antonio Alberto. EXPANSIÓN URBANA, PARANTROFITIA Y PARANTROZOOTIA... ¿BIOCENOSIS ANTROPOGÉNICAS? EL CASO DEL ÁREA METROPOLITANA DEL GRAN RESISTENCIA (A.M.G.R.), CHACO. Revista Geográfica Digital. IGUNNE. Facultad de Humanidades. UNNE. Año 11. No 22. Julio - Diciembre. 2014. ISSN 1668-5180 Resistencia, Chaco.

En: http://hum.unne.edu.ar/revistas/geoweb/default.htm 
communities associated with human groups (parantrofitia and parantrozootia respectively), they print new physiognomy and environmental dynamics.

All these mutations generate significant environmental impacts and undermine the foundations of sustainable urban development, either by the dynamism of the urban phenomenon, for economic speculation by insufficient or lax policies and, in general, due to ignorance and lack of environmental awareness in the entire community.

Keywords : Urban sprawl, environmental impacts, phytocoenoses, zoocoenosis, ruderal, arvense, parantrofitia, parantrozootia.$^{1}$

\footnotetext{
${ }^{1}$ Terms without substitutes in English:

Ruderal: Plant and animal communities typical of uncultivated land or those where waste or debris is dumped. Arvense: Communities of organisms (plants) growing in the fields.

Zoocoenosis: Communities animals.

Parantrofitia: Vegetation of man-modified environments. This vegetation is divided into arvense, ruderal and street.

Parantrozootia: Communities animals of man-modified environments.
}

Publicado en formato digital: Prof. Juan Antonio Alberto. EXPANSIÓN URBANA, PARANTROFITIA Y PARANTROZOOTIA... ¿BIOCENOSIS ANTROPOGÉNICAS? EL CASO DEL ÁREA METROPOLITANA DEL GRAN RESISTENCIA (A.M.G.R.), CHACO. Revista Geográfica Digital. IGUNNE. Facultad de Humanidades. UNNE. Año 11. No 22. Julio - Diciembre. 2014. ISSN 1668-5180 Resistencia, Chaco.

En: http://hum.unne.edu.ar/revistas/geoweb/default.htm 
Revista Geográfica Digital. IGUNNE. Facultad de Humanidades. UNNE. Año 11. № 22.

Julio - Diciembre 2014. ISSN 1668-5180 Resistencia, Chaco

\section{Desarrollo}

\section{Antecedentes}

A partir de la segunda mitad del siglo $X X$ y lo que va del presente, las ciudades en el mundo entero han alcanzado un ritmo de crecimiento notable. La expansión acelerada de urbes, tanto en tamaño como en número, es acompañada por un fenómeno conexo y paralelo, la periurbanización, es decir la propagación sostenida de la ciudad sobre los espacios rurales y naturales adyacentes y su paulatina absorción, se trata del espacio donde se efectúan prácticas agrícolas (agricultura urbana y periurbana) y pecuarias vinculadas a los mercados urbanos y donde se añaden otras actividades, no necesariamente de carácter primario. Al respecto Morello, J. y Matteucci, S. (2001) indican que en América Latina, durante las últimas tres décadas, la economía metropolitana expansiva, asociada a enormes cambios en la estructura agrícola, ha estimulado la conversión de tierras fértiles a tierras urbanas y periurbanas, conocida también como avance de la frontera urbana. En este proceso, el hombre -como sociedad organizada- es el motor de dicha expansión que demanda tierras para sí y para sus actividades, pero consciente e inconscientemente, como una consecuencias de sus acciones, es acompañado por diversas comunidades bióticas o biocensosis (fitocenosis, zoocenosis y microcenosis) ligadas a la urbanización y rápidos cambios en los usos del suelo, las que suscitan distintas suertes de sucesiones ecológicas secundarias (ambientes ruderales, viarios, arvenses y segetales) y espacios de disclimax, donde se borran las improntas de las fisonomías vegetales primigenias y aparece el dominio construido conformando espacios variables según usos y densidades de edificación.

Así, la aparición de una serie de comunidades vegetales y animales asociadas a los grupos humanos (parantrofitia y parantrozootia respectivamente), imprimen una fuerte dinámica entre lo natural y lo implantado, entre lo urbano y lo rural, afectando la biodiversidad local, las interacciones y evoluciones dentro y entre los distintos ecosistemas que conforman dicho espacio, en definitiva cambiando su paisaje.

El concepto de parantrofitia aparece citado por Fernando Urzúa Soria (2012) en un trabajo sobre malezas, anterior a éste se halla en la clasificación ecológico-fitocenótica de Huget del Villar, quien es nombrado a su vez por Salvador Rivas-Martínez (2007). También es usado en lengua portuguesa en escritos sobre especies ruderales y viarias de Celso do Lago Paiva y Ana Carla Fonseca Santos (2006), y quienes remiten a M. Kuhlmann y E. Kühn (1947). Aún así, no se tienen muchas menciones referentes a dicho término tanto en Internet como en ediciones impresas, tal vez lo consideren un tecnicismo o un neologismo, pero conceptúa muy bien el fenómeno aquí presentado, diciendo F. Urzúa Soria "es un término que se aplica a la vegetación propia de ambientes modificados por el hombre y se divide en arvense, ruderal y viaria. Una "arvense" es aquella planta que crece en forma espontánea en terrenos cultivados. Las ruderales son plantas que se desarrollan en áreas perturbadas fuera de los cultivos; y las viarias crecen a orillas de vías de comunicación. Las arvenses han evolucionado a la par de los cultivos y aprovechan las prácticas que el hombre realiza." En lo referente a las comunidades animales o zoocenosis vinculadas a los grupos humanos no se encontró un concepto similar, pero -si se me permite, por deducción y asociación con prefijos y sufijos grecolatinos, siguiendo el concepto ya enunciado para las plantas, podríamos definirla como parantrozootia, de para: en torno, referido o vinculado a; antro: anthropos: hombre, ser humano, y zootia: referido a la vida animal en sentido general, es decir comunidades animales propias de ambientes alterados por el hombre.

Al respecto, se aprecia que estas biocenosis y sus procesos asociados a la expansión urbana son objeto de estudio y preocupación con creciente interés e intervención, en especial desde las Ciencias Naturales, del Ambiente, Agronomía, Veterinaria, Geografía,

Publicado en formato digital: Prof. Juan Antonio Alberto. EXPANSIÓN URBANA, PARANTROFITIA Y PARANTROZOOTIA... ¿BIOCENOSIS ANTROPOGÉNICAS? EL CASO DEL ÁREA METROPOLITANA DEL GRAN RESISTENCIA (A.M.G.R.), CHACO. Revista Geográfica Digital. IGUNNE. Facultad de Humanidades. UNNE. Año 11. No 22. Julio - Diciembre. 2014. ISSN 1668-5180 Resistencia, Chaco.

En: http://hum.unne.edu.ar/revistas/geoweb/default.htm 
Revista Geográfica Digital. IGUNNE. Facultad de Humanidades. UNNE. Año 11. № 22.

Julio - Diciembre 2014. ISSN 1668-5180 Resistencia, Chaco

Urbanismo y Arquitectura, obviamente cada especialista imprime una percepción y valoración particular, sustentadas en el cuerpo teórico, metodología y técnicas de investigación propias y específicas de su área de conocimiento. Vale mencionar que sobre este tema se recaba profusa y heterogénea producción tanto en formato impreso como en Internet, si bien dicho trabajos no versan exactamente -en lengua hispana en general- sobre estos fenómenos y procesos con visión paisajística y ecogeográfica; si se denota con más precisión esta orientación en publicaciones en francés y en inglés. Por ejemplo una buena discriminación de este tipo de comunidades y ambientes consecuentes es presentada por Jean Terrisse (2012) en Terrains piétinés et rudéraux y por Klaus, Gregor (2003) en Ville et nature: y a-t-il vraiment incompatibilité? No obstante, con una visión ecológica y holística ambiental existen muy buenos trabajo de investigadores de España y Latinoamérica referido a biodiversidad urbana, ambientes ruderales en general y específicamente a plantas y comunidades invasoras o malezas en distintos ambientes, como consecuencia de procesos de antropización diversos y diferentes usos del suelo, por ejemplo el trabajo de Raimundo Real Jiménez La ciudad y la biodiversidad urbana; o Juan Javier García-Abad Alonso con Biogeografía urbana: presentación del caso de Alcalá de Henares. Lo mismo ocurre al abordarse zoocenosis y expansión urbana, como en la investigación sobre ciudad y fauna urbana de Marcela Alejandra Sierra Vásquez, (2012). También, no menos importante son los numerosos y detallados estudios específicos sobre taxones propios de estas comunidades, haciendo inventarios minuciosos de estos, de sus características y sus impactos en la dinámica ambiental, como lo expuesto por S. Lowe et al (2004)., quienes se refieren a las especies exóticas invasoras más dañinas del mundo, por su parte M. Vilà et al (2006) investigan sobre las invasiones de plantas y vertebrados terrestres en Europa, o Pedro N. Acha y Boris Szyfres (2001) que detallan los problemas de zoonosis y grupos humanos. A nivel nacional incursionan en estos temas el equipo del GEPAMA (Grupo de Ecología del Paisaje y Medio Ambiente de la Universidad de Buenos Aires), grupo académico interdisciplinario integrado principalmente por ecólogos, geógrafos, biólogos e ingenieros agrónomos; y en el ámbito local lo hacen investigadores del I.P.U.R. de la Facultad Arquitectura y Urbanismo, y del Instituto de Geografía, de la Facultad de Humanidades, ambos de la Universidad Nacional del Nordeste (UNNE), por citar someramente algunos testimonios.

\section{Materiales y Métodos.}

La presente comunicación resulta de las bases teóricas y apreciaciones empíricas sobre el fenómeno de expansión urbana asociado a sus paisajes y problemas derivados, juicios que están acotados al Área Metropolitana del Gran Resistencia (AMGR), en la Provincia del Chaco, y que son consideraciones y juicios preliminares del trabajo de investigación "Expansión Urbana y Ambiente. Huella Ecológica y Desarrollo Sostenible. El Caso del Área Metropolitana del Gran Resistencia (AMGR)", que se realiza en el Departamento e Instituto de Geografía, de la Facultad de Humanidades, UNNE.

Se trabaja aquí con una metodología para el estudio del paisaje, apoyada en una concepción geográfica y ambiental y recursos técnicos metodológicos de la Geografía, de las Ciencias Naturales y de la Tierra; la misma responde a la necesidad de analizar y caracterizar el proceso de urbanización; valiéndose para ello de bases cartográficas, de síntesis e históricas, complementadas con fotografías aéreas e imágenes satelitales y trabajos de observación y registros en el terreno, en especial los atinentes a la vegetación y los animales. Estos trabajos de campo, dada la extensión del área de estudio, se realizan - en diferentes épocas del año- en puntos o superficies de muestreos, comprendiendo sectores de las rutas nacionales $\mathrm{n}^{0} 11$ y 16 (Autovía N. Avellaneda), Avenidas Sabin, 25 de mayo, Avalos, Hernandarias, Lavalle, Laprida, Las Heras, Velez Sharfield, Castelli, Alvear, Malvinas Argentina, Soberanía Nacional, San Martín (Barranqueras), Defensa Norte y caminos vecinales próxi-

Publicado en formato digital: Prof. Juan Antonio Alberto. EXPANSIÓN URBANA, PARANTROFITIA Y PARANTROZOOTIA... ¿BIOCENOSIS ANTROPOGÉNICAS? EL CASO DEL ÁREA METROPOLITANA DEL GRAN RESISTENCIA (A.M.G.R.), CHACO. Revista Geográfica Digital. IGUNNE. Facultad de Humanidades. UNNE. Año 11. No 22. Julio - Diciembre. 2014. ISSN 1668-5180 Resistencia, Chaco.

En: http://hum.unne.edu.ar/revistas/geoweb/default.htm 
mos, acceso antiguo y nuevo a Colonia Benítez, Barrio Don Santiago y Villa Cristo Rey, Paraje El Tropezón, Lagunas Argüello, Avalos, Colussi, Francia Argentina, de Va. Los Lirios, río Negro, riacho Arazá y arroyo Ojeda. A su vez, los recursos metodológicos citados están orientados al uso de herramientas informáticas que permitan analizar y evaluar las diferentes variables ambientales.

A la hora del uso -en este tipo de estudios- de S.I.G., modelos e indicadores (como por ejemplo NDVI) se sugiere tener precaución en la selección de imágenes bases y registros esporádicos, ya que responden a un momento concreto por ende reflejan la situación ambiental de ese tiempo preciso, pudiendo llevar a yerros o percepciones tergiversadas. Estos recursos técnicos deben acompañarse con imágenes de distintos períodos, reflejando ciclos estacionales típicos, ciclos húmedos y secos anormales, como también fenómenos locales (blanquizales, fachinales, grandes préstamos de tierra, diferentes tipos de humedales, usos tradicionales del suelo, nubosidad, albedo y sombras estacionales, etc.), para no caer en una concepción científica simplista y utilitaria, donde sólo interese el producto (mapa, plano u ortofoto) ya que, por un lado, estamos dejando el rico proceso de elucubración del investigador avezado a un programa o varios y a un artefacto - la PC, y por otro, más allá de la localización (principio básico de la Geografía) debemos apuntar a explicación de causas, interacciones y dinámica, evolución, posibles tendencias futuras y recomendaciones propedéuticas. Todo este tipo de recursos, interesantes y prometedores por cierto, deben ser acompañados por trabajos de campos, recolección de pruebas y registros fotográficos, muestreos y observaciones periódicas, y -más en el caso de novicios en el tema- una buena compulsa bibliográfica y consultas de sitios Web idóneos.

A través de esta propuesta de investigación se proyecta compendiar y proporcionar una base general para el tratamiento de la información sobre la historia ecológica del Gran Resistencia y sus zonas aledañas, centrada en la tipificación y caracterización de sus paisajes a través de sus Componentes Paisajísticos de Interés Ambiental (C.P.I.A.), Alberto, Juan Antonio (2013), como así también perfilar las tendencias paisajísticas resultantes de la evolución de los procesos naturales y humanos estudiados y sus alcances en la sustentabilidad ambiental, cuerpo de información actualmente prolífero y diseminado en distintas fuentes y organismos.

\section{APRECIACIONES Y FUNDAMENTACIONES}

\section{Un Fenómeno Mundial y Un Caso Particular: El A.M.G.R.}

Las ciudades son la máxima expresión de intervención humana en el ambiente, pues los grupos humanos primero al asentarse en el espacio conformando el centro urbano y luego expandirlo a través del proceso de urbanización, generan un nuevo ambiente, un ecosistema artificial, calificado como parásito por muchos especialistas en el tema, ya que toma energía y recursos varios de otros ecosistemas, vecinos en algunos procesos, lejanos en otros, mientras por otro lado genera un cúmulo de desecho que contaminan y menoscaban la calidad del suelo, aire y agua del sitio que ocupa y de espacios circundantes (periurbanos y rurales), acciones que remarcan sus riesgos y vulnerabilidades. Hechos y consecuencias que se conjugan con otras formas de apropiación y organización social del espacio (agrosistemas, ámbitos rururbanos y vorurbanos, áreas mineras, etc.), procesos todos que ocurren en un entorno humanizado, es decir, en un territorio, y que se manifiestan a través del paisaje o construcción social creada a partir de la percepción colectiva del mismo.

A partir de los años 50 del siglo XX el fenómeno de expansión urbana, tanto en tamaño como en número de urbes ha adquirido un notable impulso. Los datos analizados señalan de manera evidente que la expansión urbana exagerada y desordenada, repitiendo el fenómeno urbano mundial, ha acompañado al crecimiento de las ciudades argentinas y de la

Publicado en formato digital: Prof. Juan Antonio Alberto. EXPANSIÓN URBANA, PARANTROFITIA Y PARANTROZOOTIA... ¿BIOCENOSIS ANTROPOGÉNICAS? EL CASO DEL ÁREA METROPOLITANA DEL GRAN RESISTENCIA (A.M.G.R.), CHACO. Revista Geográfica Digital. IGUNNE. Facultad de Humanidades. UNNE. Año 11. № 22. Julio - Diciembre. 2014. ISSN 1668-5180 Resistencia, Chaco.

En: http://hum.unne.edu.ar/revistas/geoweb/default.htm 
región durante los últimos 50 años, como sucede con el Área Metropolitana del Gran Resistencia (A.M.G.R.), objeto de este estudio. (Fig. 1)

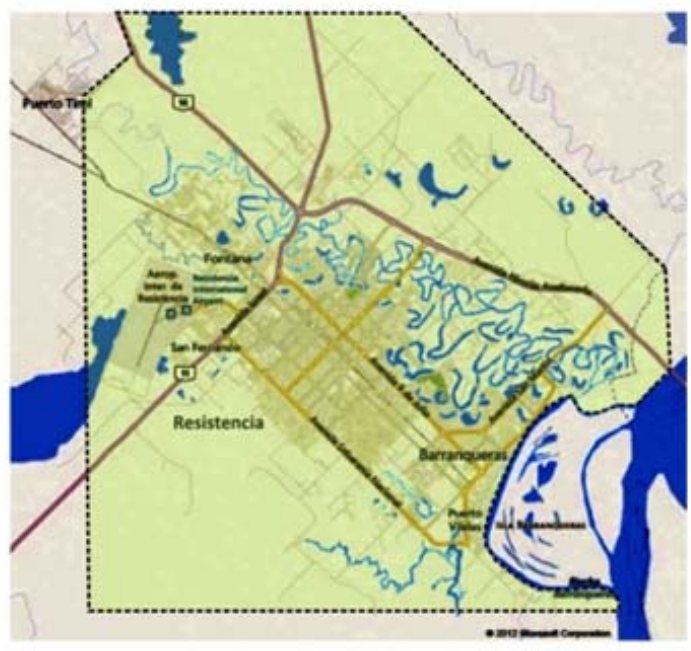

Área de estudio
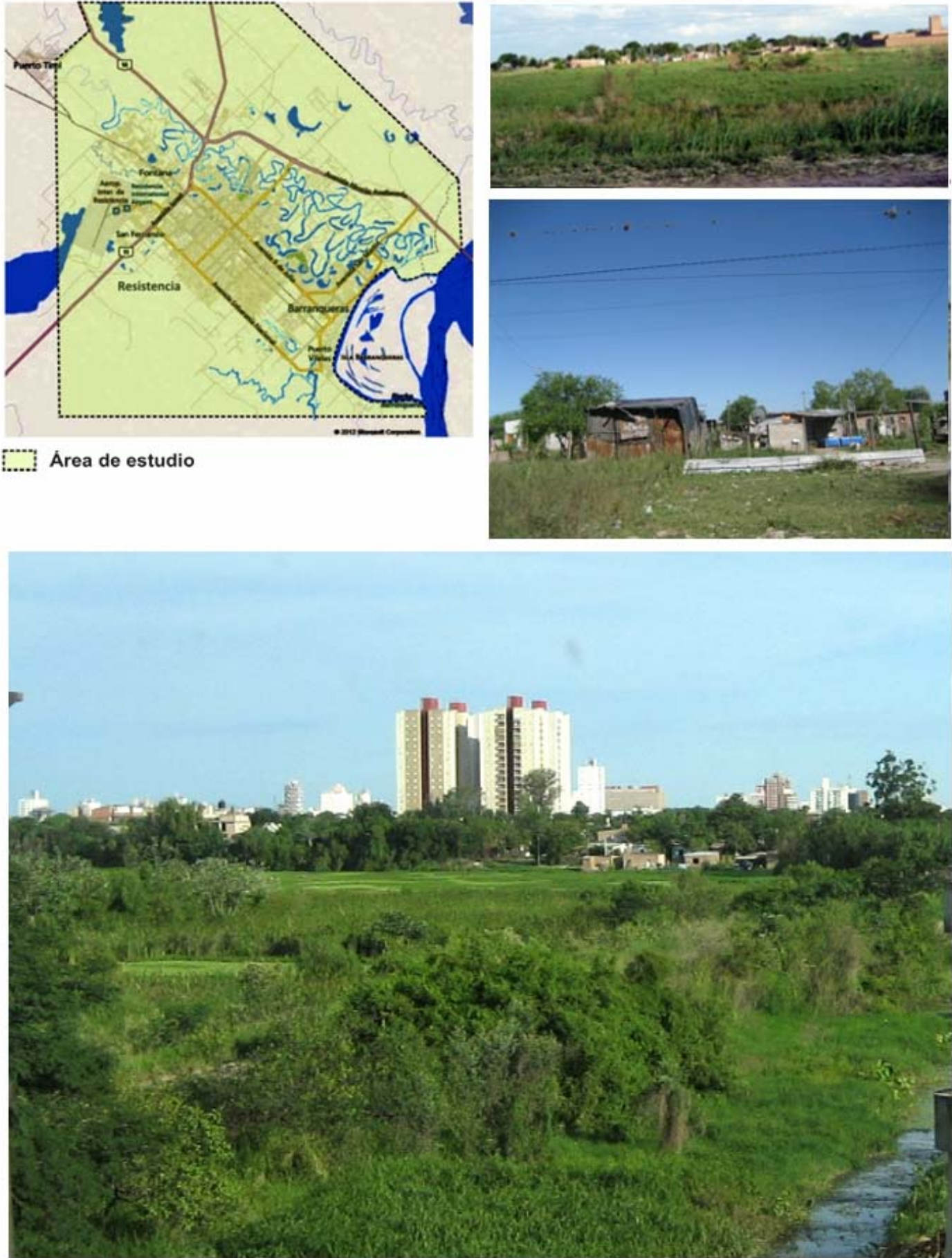

Fig. 1: Área de estudio. Paisajes urbanos y periurbanos del AMGR. Un pachtwork de ambientes y paisajes consecuentes.

En nuestro caso, la expansión urbana, y en particular la evolución del conurbano A.M.G.R. muestra claramente estos fenómenos y sus problemas. Como lo expresa muy bien para el caso de México el Centro Mario Molina para Estudios Estratégicos sobre Energía y

Publicado en formato digital: Prof. Juan Antonio Alberto. EXPANSIÓN URBANA, PARANTROFITIA Y PARANTROZOOTIA... ¿BIOCENOSIS ANTROPOGÉNICAS? EL CASO DEL ÁREA METROPOLITANA DEL GRAN RESISTENCIA (A.M.G.R.), CHACO. Revista Geográfica Digital. IGUNNE. Facultad de Humanidades. UNNE. Año 11. No 22. Julio - Diciembre. 2014. ISSN 1668-5180 Resistencia, Chaco.

En: http://hum.unne.edu.ar/revistas/geoweb/default.htm 
Medio Ambiente (2013), citado por Marín, Nidia (2014), indicando que nuestras ciudades crecen de acuerdo con un modelo de ocupación del territorio en 3D (Distante, Disperso y Desconectado), puesto de manifiesto por la expansión desproporcionada, fragmentada y no planificada de la mancha urbana.

En efecto, el Área Metropolitana del Gran Resistencia (AMGR) no escapa a la realidad enunciada. Vinculados a ella, intentamos mostrar aquí las rápidas mutaciones ecosistémicas y reemplazos en las biocenosis, reflejados en parte por los constantes cambios paisajísticos y sus problemas asociados, tanto en el espacio urbano del AMGR como en sus fronteras urbanas, espacios signados por su transición hacia ambientes rurales y naturales, que se transforman en ámbitos de fusión, riesgos, vulnerabilidades y conflictos entre lo ambiental y lo social y todas las connotaciones asociadas.

Sin dudas, este patrón de crecimiento urbano impacta fuertemente en el ambiente, afectando tanto a las biocenosis como al biotopo, ya que el avance de la mancha urbana urbanización y periurbanización- en forma de parches, acompañada a su vez por las infraestructuras de servicios, fragmentan hábitats, degradan o eliminan ecosistemas, alteran la dinámica hídrica, los procesos sedimentarios y de edafogénesis, cambiando con fuerte dinamismo sus paisajes, diferenciados en urbanos, suburbanos, vorurbanos, rururbanos y rurales enmarcados por los paisajes naturales, propios del sitio donde se originó el centro urbano y sobre el cual crece.

Cuando se urbaniza una determinada zona, ya sea natural o rural, el impacto persiste durante siglos o incluso nunca llega a desaparecer. El uso de tierras agrícolas o incultas para la construcción de viviendas o infraestructuras produce un impacto que suele ser persistente, y sólo en algunas ocasiones reversible, pero con un coste muy elevado. El proceso paulatino de urbanización extensa ha propiciado que se borren definitivamente los límites entre lo realizado por el hombre y el territorio aparentemente libre de su huella, generando un paisaje caracterizado por su dependencia de lo urbano. Lo urbano, en ese sentido, debe ser considerado como una segunda naturaleza, como un gran ecosistema dentro del cual los flujos de energía y materia planetarios de origen solar se ven sometidos a transformaciones y modificaciones al servicio de la compleja red de elementos que lo forman.

Así, según Raimundo Real Jiménez (2009) el ecosistema urbano que difiere esencialmente de los biotopos naturales en varios aspectos fundamentales, es el más reciente de los que existen sobre la Tierra. No obstante, en la actualidad se está expandiendo vertiginosamente, por primera vez en la historia de la humanidad, el umbral del $50 \%$ de la población humana global está residiendo en núcleos urbanos.

Entretanto en las ciudades, paralelamente al fenómeno sociodemográfico, se desarrollan una serie de comunidades vegetales y animales adaptadas a las condiciones ecológicas altamente transformadas que caracterizan a los sistemas urbanos. Además de las especies cosmopolitas que se han adaptado a los medios artificiales y los animales domésticos, existe un contingente de poblaciones bióticas que pueden colonizar los pueblos y ciudades gracias a la existencia de las zonas verdes, baldíos, corredores naturales (ríos, arroyos, esteros) y artificiales (rutas, caminos, senderos, canales, picadas -pasajes de servidumbre de paso- con tendidos de cables de energía eléctrica u otros servicios, etc.).

De esta forma, cuando recorremos senderos, veredas y calles de nuestras ciudades, más aún cuando transitamos por sus espacios periurbanos, advertimos la presencia de ciertas fisonomías vegetales típicas que, -con visión simplista- catalogamos de arboledas o bosques, pastizales, baldíos con matorrales, o peor que con sentido despectivo y toponimia local encasillamos como "mogotes", "yuyales", "gramillares", "malezales", etc. Pero si observamos con atención, afinando la visión y ajustando nuestra percepción, veremos mucho más... pues estamos frente a la presencia de biocenosis o comunidades de organismos (plantas, animales, microorganismos, hongos) estrechamente asociados e interactuando

Publicado en formato digital: Prof. Juan Antonio Alberto. EXPANSIÓN URBANA, PARANTROFITIA Y PARANTROZOOTIA... ¿BIOCENOSIS ANTROPOGÉNICAS? EL CASO DEL ÁREA METROPOLITANA DEL GRAN RESISTENCIA (A.M.G.R.), CHACO. Revista Geográfica Digital. IGUNNE. Facultad de Humanidades. UNNE. Año 11. № 22. Julio - Diciembre. 2014. ISSN 1668-5180 Resistencia, Chaco.

En: http://hum.unne.edu.ar/revistas/geoweb/default.htm 
entre sí y con los grupos humanos que comparten su espacio o biotopo, es decir verdaderos ecosistemas... aunque sus causas y sustentos no sean del todo naturales.

Vale recordar que la impronta generada por estas comunidades biológicas, junto con los impactos de las acciones humanas y la dinámica que mueve a ambas, se refleja en la realidad y se traduce y perpetúa en las imágenes satelitales, fotografías aéreas y cartografía -en general- en un trabajado tapiz o en un mosaico heterogéneo de estructuras fragmentadas -"Patrón del Arlequín. Así, la estructura de los nuevos paisajes urbanos, según Hough, M. 1998 citado por Sierra Vásquez, Marcela Alejandra (2012, pag.11), consta de tres elementos principales: manchas (terrenos arbolados, pastizales u otras asociaciones rodeados de espacios urbanos), matrices (áreas homogéneas con manchas dentro de ella) y corredores (espacios verdes como rutas a lo largo de corredores de agua, a lo que agregamos ejes lineales artificiales de prestación de servicios o delimitación.). En nuestro caso podríamos hablar de las matrices: ambiente antrópico (Urbanización A.M.G.R. y sus proyecciones en espacio periurbano), ambiente natural o sitio (sitio sobre el que se proyecta el conurbano, compuesto por las principales formaciones vegetales con dominancia espacial y su soporte edafotopográfico); las manchas o parches conformadas por terrenos de distintos tamaños que integran las matrices enunciadas (bosques, pastizales, palmares, esteros, diferentes espacios construidos o con usos típicos del suelo -ladrillerías, tambos, huertas, basurales, etc.) y los corredores esbozados por la red hidrográfica con cursos de distinta extensión, dinámica y regularidad (ríos, riachos, arroyos) y redes lineales regulares (rutas, autovias, calles, caminos, vías férreas, sistemas de defensas contra inundaciones, tendidos de red eléctrica y otros servicios por cable sumados a cualquier servidumbre de paso o instalaciones de delimitación, por ejemplo canales, acequias, alambrados, vallas), y redes lineales iregulares como sendas, callejones, setos. (Fig. 2).

En nuestro caso particular, siguiendo esta tendencia, el gran sistema urbanoperiurbano del A.M.G.R. al expandirse activamente se diluye en espacios urbanos confusos y adquiere la singularidad de un pachtwork, configurado por zonas muy diversas y superficies con diferentes formas de usos predominantes, sobre un marco natural original de bosques, matorrales, pastizales, esteros, bajos, cañadas y palmares propios de la fisonomías vegetales del Chaco Oriental, que revelan diferencias de micro relieves y leves pendientes, variaciones en la mecánica hídrica y permanencia del agua como también variedades edáficas concomitantes, determinando una fuerte dinámica entre lo natural y lo artificial, entre lo urbano y lo rural que suscitan en la naturaleza distintas suertes de sucesiones ecológicas secundarias (ambientes ruderales, viarios, arvenses y segetales) y espacios de disclimax, donde se borran las improntas de las fisonomías vegetales primigenias y aparece el espacio construido conformando espacios variables según usos y densidades de edificación. Lógicamente, en los resquicios o relictos urbanos verdes, se encuentran, por lo general hábitats ricos en fauna y vegetación, los que puede estar en concordia con los procesos y funciones de la ciudad, encontrando su óptimo ecológico precisamente en los espacios urbanos (Raimundo Real Jiménez, 2009),

No está demás mencionar que este mosaico de paisajes vegetales naturales está muy degradado o ha desaparecido del área de expansión urbana del AMGR y se caracteriza por tener un equilibrio dinámico con alta fragilidad o vulnerabilidad natural y ecológica, de tal forma que por causas naturales - ciclos secos y húmedos o por actividades humanas que alteren los ejes de escurrimiento o obstaculicen los mismos (terraplenes, trazado de calles, nivelación de predios, etc), que rellenen sus cauces y cuencas, etc. se infringirán cambios en su estructura y dinámica, pasando por ejemplo de hidroseres a xeroseres o viceversa, es decir unos ambientes evolucionaran hacia formaciones higrófilas e hidrófilas y otros hacia comunidades mesófilas y xerófilas. Estas últimas, especialmente los pastizales y bosques periurbanos degradados, se transforman en época de sequías prolongadas en verdaderos

Publicado en formato digital: Prof. Juan Antonio Alberto. EXPANSIÓN URBANA, PARANTROFITIA Y PARANTROZOOTIA... ¿BIOCENOSIS ANTROPOGÉNICAS? EL CASO DEL ÁREA METROPOLITANA DEL GRAN RESISTENCIA (A.M.G.R.), CHACO. Revista Geográfica Digital. IGUNNE. Facultad de Humanidades. UNNE. Año 11. No 22. Julio - Diciembre. 2014. ISSN 1668-5180 Resistencia, Chaco.

En: http://hum.unne.edu.ar/revistas/geoweb/default.htm 
focos ígneos, por la acción irracional y desaprensiva de muchos ciudadanos, que con incendios de difícil control pueden atentar contra la seguridad de bienes y personas de los barrios perimetrales próximos, como así también contaminar con humos, cenizas y fuertes olores el aire urbano y suburbano.

PAISAJES NATURALES DEL A.M.G.R (Fisonomías Vegetales)
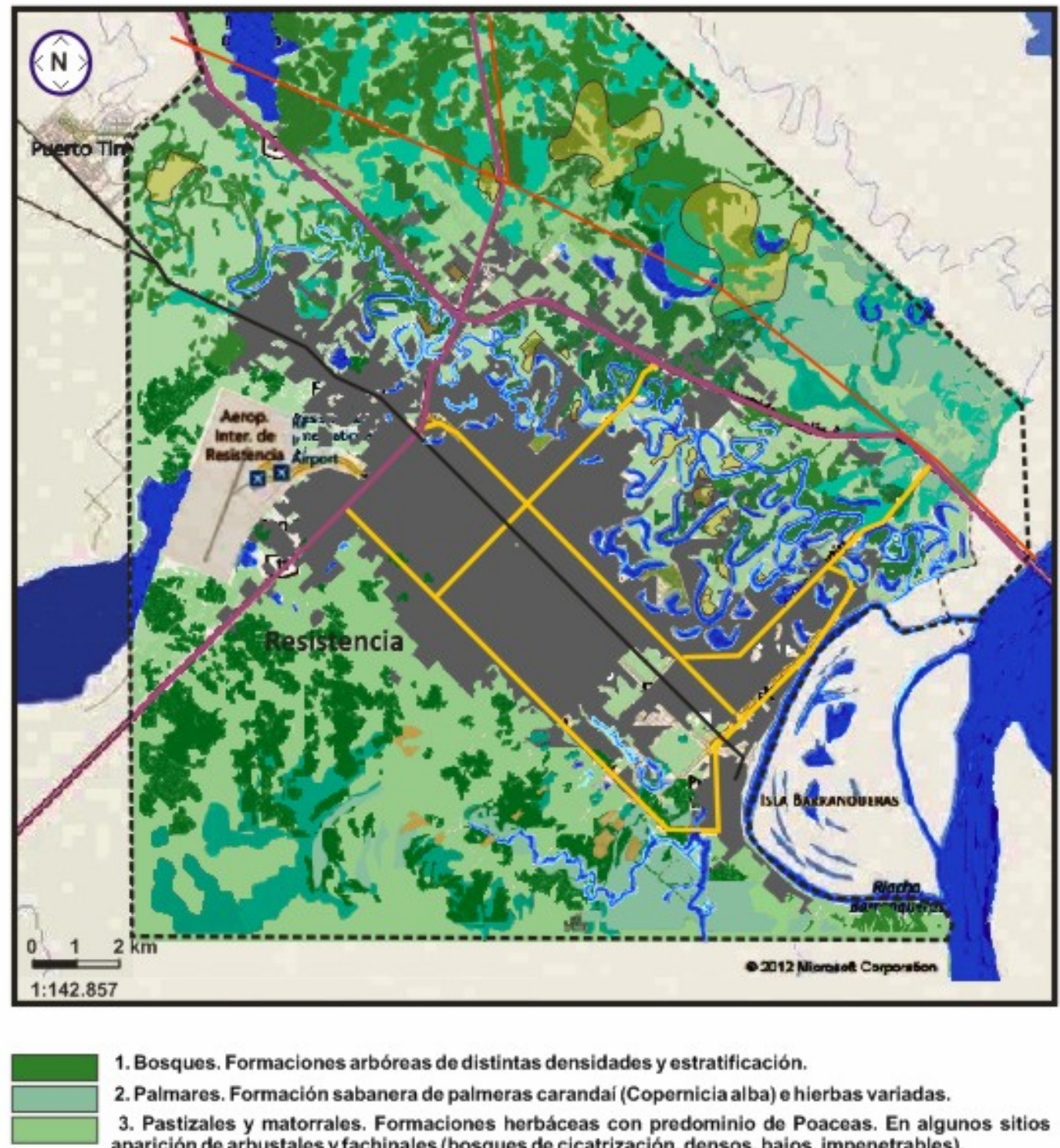

1. Bosques. Formaciones arbóreas de distintas densidades y estratificación.

2. Palmares. Formación sabanera de palmeras carandai (Copernicia al ba) e hierbas variadas.

3. Pastizales y matorrales. Formaciones herbáceas con predominio de Poaceas. En algunos sitios aparición de arbustales y fachinales (bosques de cicatrización, densos, bajos, impenetrables).

4. Esteros, cañadas y bajos (cangrejales). Formaciones herbáceas higrófilas, estacionalmente inundadas. Ambientes lóticos.

5. Red hidrográfica. Ríos y lagunas. Ambientes lóticos y lénticos. Organismos hidrófilos e higrófilos. 6. Mancha urbana (área edificada y adyacencias vinculadas a edificios-patios, veredas, etc).

7. Paisajes vorurbanos y rurales (pequeñas chacras, huertas, tambos)

8. Rutas y autovias.

9. Avenidas de acceso y circunvalación.

10. Ferrocarril interurbano y Belgrano cargas.

Fig. 2. A.M.G.R. Paisajes Naturales, Mancha Urbana y Grandes Ejes de Comunicación

Publicado en formato digital: Prof. Juan Antonio Alberto. EXPANSIÓN URBANA, PARANTROFITIA Y PARANTROZOOTIA... ¿BIOCENOSIS ANTROPOGÉNICAS? EL CASO DEL ÁREA METROPOLITANA DEL GRAN RESISTENCIA (A.M.G.R.), CHACO. Revista Geográfica Digital. IGUNNE. Facultad de Humanidades. UNNE. Año 11. No 22. Julio - Diciembre. 2014. ISSN 1668-5180 Resistencia, Chaco.

En: http://hum.unne.edu.ar/revistas/geoweb/default.htm 
Vale plantearse entonces sí las nuevas biocenosis (fito, zoo y microcenosis) que ocupan habitats y nichos ecológicos, modificados, dejados o creados por los impactos de la antropocenosis urbana y periurbana (suburbana, rururbana, vorurbana y rural) se constituyen en biocenosis antropogénicas y ecosistemas antropizados, ya que sus procesos, ciclos e interacciones son fuertemente injeridos por los grupos humanos y sus obras, al punto que su conformación y persistencias dependen en gran medida de estos, pues imprimen una nueva dinámica y fisonomías o paisajes consecuentes a estos ambientes, otrora naturales en el sentido estricto del concepto. Fig. 3

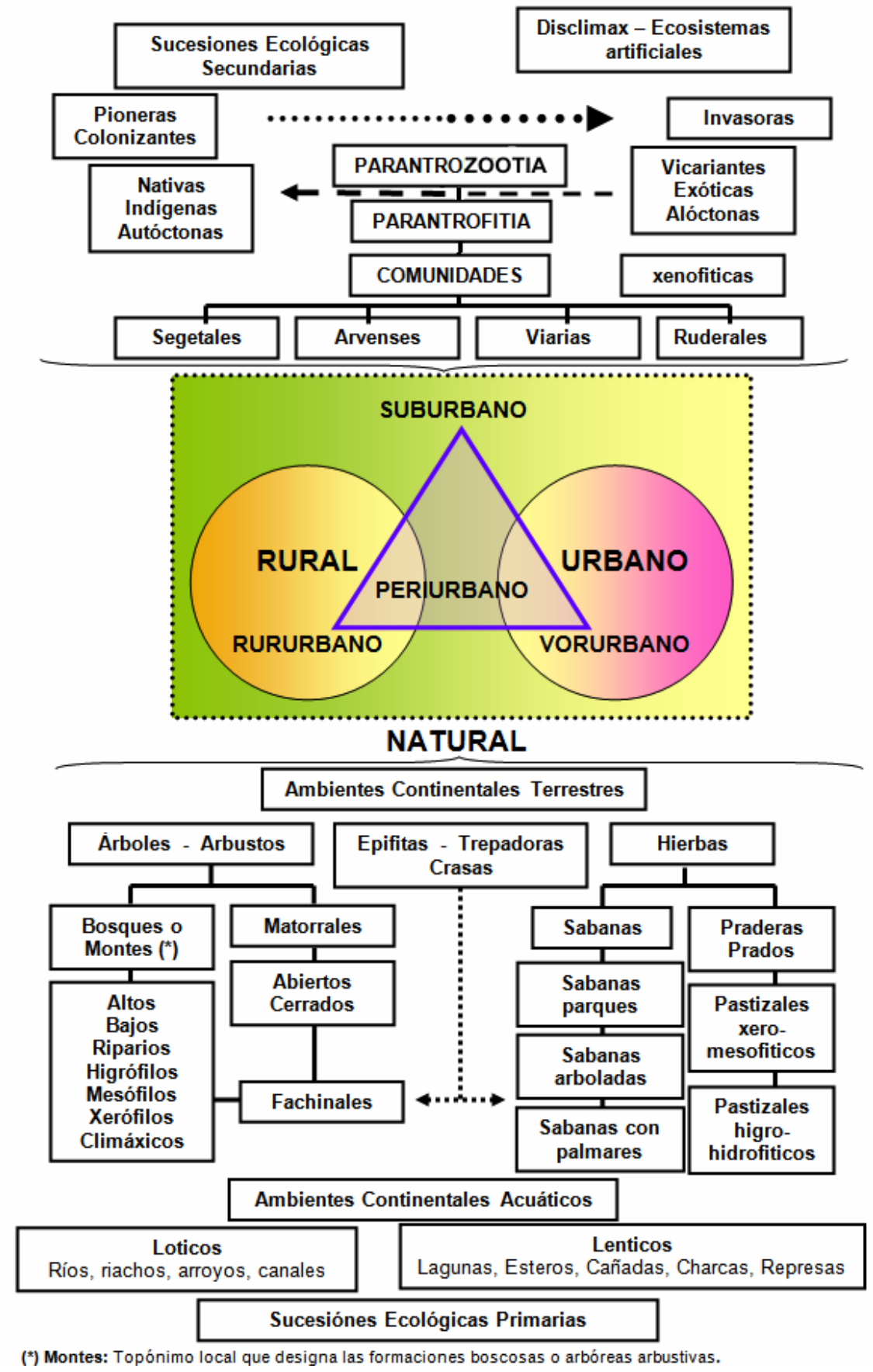

Fig. 3: Ambientes y Biocenosis más frecuentes que conforman los paisajes urbanos y periurbanos en el AMGR

Publicado en formato digital: Prof. Juan Antonio Alberto. EXPANSIÓN URBANA, PARANTROFITIA Y PARANTROZOOTIA... ¿BIOCENOSIS ANTROPOGÉNICAS? EL CASO DEL ÁREA METROPOLITANA DEL GRAN RESISTENCIA (A.M.G.R.), CHACO. Revista Geográfica Digital. IGUNNE. Facultad de Humanidades. UNNE. Año 11. No 22. Julio - Diciembre. 2014. ISSN 1668-5180 Resistencia, Chaco.

En: http://hum.unne.edu.ar/revistas/geoweb/default.htm 
Al respecto, recordemos que de acuerdo con el grado de perturbación o intensidad de la actividad humana, las especies de fauna y flora en los ambientes urbanos varían en composición y proporciones al verse beneficiados o excluidos (Faggi et al., 2006); es decir, en función de su posibilidad de adaptarse son hospedados o ahuyentados, determinando un medio ambiente urbano en mayor o menor medida acogedor u hospitalario en términos físico-espaciales.

La parte más visible de estos ambientes y su biota particular, es la parantrofitia, es decir las fitocenosis propias de ambientes modificados por el hombre. A grandes rasgos podríamos diferenciar a estos ambientes y sus paisajes más o menos antropizados en: urbano, rural (agrosistemas y otras actividades primarias como ganadería y explotación forestal), vorurbanos, rururbanos y suburbanos, insertos y expandiéndose sobre el ambiente natural que le sirve de soporte. Cada uno de estos ambientes contiene diferentes fitocenosis con distintos grados de antropización, que pueden darse simultáneamente próximas o distantes, o conformar series dando paso a sucesiones ecológicas secundarias, y que siguiendo a especialistas consultados, muchos aquí citados, podríamos clasificarlas en comunidades vegetales ruderales, viarias, arvenses y segetales (Figs. 5, 6 y 8 ), que sirve de hábitat tanto a la fauna urbana como a ejemplares de la fauna silvestre. Por otra parte atendiendo al área urbanizada, en general se pueden distinguir dos grandes tipos de reductos citadinos de vegetación: los lugares no usados y/o abandonados por el hombre (baldíos, techos, cercos y muros) -los ruderales enunciados antes, que son colonizados por la vegetación existente en zonas próximas (nativa y exótica), y los que forman parte del "verde" urbano" creado artificialmente por el hombre (arbolado lineal, vegetación interior a las viviendas y edificaciones y, sobre todo, parques y jardines); en nuestro caso -A.M.G.R.- dentro del primer tipo podríamos incluir los ambientes lóticos (río Negro, riacho Arazá y arroyos Quintana y Soto) y lenticos (lagunas y bajos) que quedaron encerrados por la urbanización creciente y cuyas cuencas se hallan muy alteradas y degradadas. (Figs. 1 y 2).

Muchos de los vegetales que prosperan en estos ambientes son considerados malezas, malas hierbas o plagas -concepto este último compartido con poblaciones animales y de microbios- por afectar la salud o algunos intereses o patrimonios de los grupos humanos (cultivos, ganado, infraestructuras, aguas, estética paisajística y tierras fértiles) y además resultan difíciles de extirpar; sin embargo según el Dr. Elías D. Dana (2003) las categorizaciones de este tipo de organismos suelen ser antropocéntricas y algo subjetivas. Este grupo de plantas -nativas (autóctonas o indígenas), o adventicias o exóticas (introducidas, alóctonas)- posee ciertas peculiaridades que las aglutina, ya que su éxito para ocupar ambientes ruderales, arvenses y viales se debe a sus estrategias reproductoras muy eficaces y a su gran amplitud ecológica o alta resistencia a condiciones ambientales dispares, ya que suelen presentar un ancho rango ecológico (es decir, son muy resistentes a situaciones adversas), tolerando amplias series de condiciones climáticas y edáficas. Al respecto, de acuerdo con fundamentos biológicos y ecológicos podemos decir que:

- son plantas pioneras de sucesiones secundarias (es decir, las que ocurren en terrenos no vírgenes; por ejemplo un campo en barbecho, una construcción abandonada, terrenos deforestados, etc.) es decir, son plantas que crece sin haberlas sembrados, se propagan de forma natural y pueden ocasionar algún daño a los intereses o calidad de vida humana. En nuestro caso son frecuentes plantas de las familias Poaceae (Gramineae) p.e. Sorgo de Alepo o pasto ruso (Sorghum halepense (L.) Persoon), Asteraceae (Compositae) como el Cardo negro (Cirsium vulgare), Solanaceae con algunas especies tóxicas como el Chamico o Datura (Datura feroz $L$ ), Fabaceae (Leguminoseae) p.e. el pega-pega o voy contigo (Desmodium incanum), y Cyperaceae, a la cual pertenece el temido cebollín (Cyperus rotundus); (Fig. 4)

Publicado en formato digital: Prof. Juan Antonio Alberto. EXPANSIÓN URBANA, PARANTROFITIA Y PARANTROZOOTIA... ¿BIOCENOSIS ANTROPOGÉNICAS? EL CASO DEL ÁREA METROPOLITANA DEL GRAN RESISTENCIA (A.M.G.R.), CHACO. Revista Geográfica Digital. IGUNNE. Facultad de Humanidades. UNNE. Año 11. No 22. Julio - Diciembre. 2014. ISSN 1668-5180 Resistencia, Chaco.

En: http://hum.unne.edu.ar/revistas/geoweb/default.htm 
- son plantas oportunistas, espontáneas y persistentes, adaptadas a proliferar en hábitats continuamente alterados por el hombre, que no son deseables en determinados lugares y momentos e interfieren con las actividades de éste;

- son plantas que impiden o dificultan el aprovechamiento de los nutrientes, el agua o la luz a las plantas cultivadas, tanto para ser recolectadas por el hombre o consumidas por el ganado, o que interfieren en actividades humanas, ya que suelen ser plantas con altas tasas de crecimiento y absorción de nutrientes (es decir, son 'vigorosas'), sobre todo las que cuentan con órganos de reserva, y su biomasa puede sobrepasar a las cultivadas. Igual presión ejercen sobre la vegetación silvestre como invasoras o colonizantes.

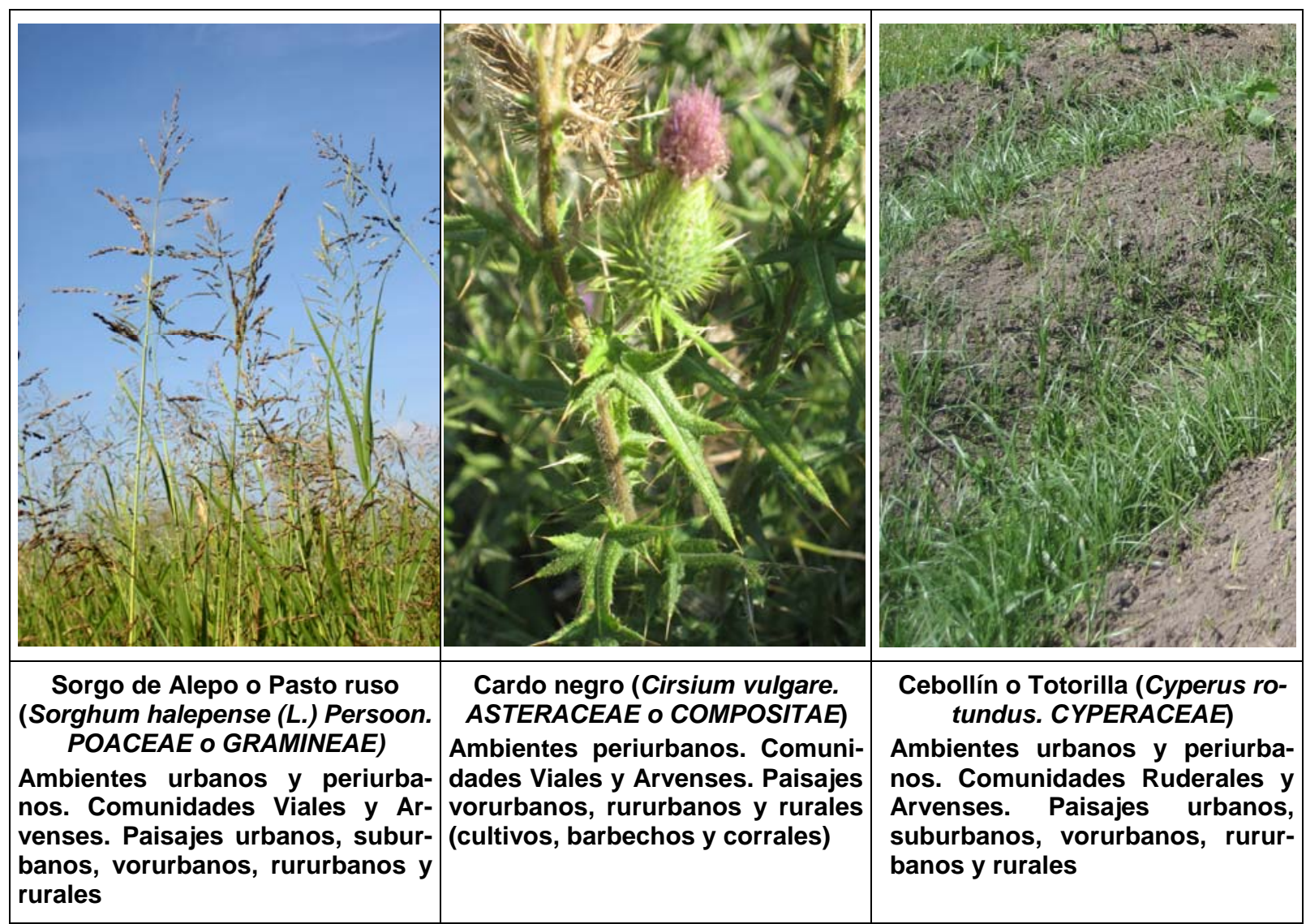

Fig. 4. Malezas frecuentes en nuestros paisajes urbanos y periurbanos. Ejemplos de parantrofitia.

Además, son plantas que poseen las siguientes estrategias:

1- Las semillas $u$ otros propágulos pueden permanecer viables mucho tiempo, en fase de latencia, lo que dificulta su erradicación; por ejemplo el ya citado cebollín (C. rotundus) ya que su reproducción principal es vegetativa, engendrando cada planta entre 60 y 120 tubérculos en cada ciclo, que originarán entre 25 y 40 nuevos brotes. La mayoría de los mismos se producen en los primeros $15 \mathrm{~cm}$. de profundidad. No todos los tubérculos brotan en primavera, sino que presentan dormancia.

2- La dispersión de sus semillas es fácil: viento (anemocoría), agua (hidrocoría) o ambos (anemohidrocoría), animales (zoocoría) e inclusive en la ropa de los que pasen junto a ellas, mezcladas con las simientes de los cultivos, adheridas a herramientas, etc.(antropocoría). Como ejemplo del primer grupo la mayoría de las Poaceas y AsteTROZOOTIA... ¿BIOCENOSIS ANTROPOGÉNICAS? EL CASO DEL ÁREA METROPOLITANA DEL GRAN RESISTENCIA (A.M.G.R.), CHACO. Revista Geográfica Digital. IGUNNE. Facultad de Humanidades. UNNE. Año 11. № 22. Julio - Diciembre. 2014. ISSN 1668-5180 Resistencia, Chaco. 
ráceas, en el segundo y tercero: las Ciperáceas, Poacaeas hidrófilas e higrófilas, géneros Azollas y Lemma (helechos y lentejas de agua), Cannáceas (Achiras), Tiphas (totoras o espadañas) y Talhya (peguajós), en el cuarto grupo por exozoocoría: Cenchrus (cadillos), Xanthium (abrojos), Bidens pilosa (amor seco), Desmodium incanum (pegua pegua o voy contigo), y por endozoocoría: Citrus aurantium var. amara $L$. (naranjo amargo), Carica papaya (mamón o papaya), Psidium guajava (guayaba), Allophylus edulis (cocú), Eugenia uniflora (ñangapirí), Eugenia pungens (guaviyú, ivá viyú, ibá porei), Bromeliáceas varias (plantas similares al ananá) y Cactáceas (tunas y cactus); y en el cuarto: las citadas como zoocoras más otras que el hombre conciente o inconcientemente dispersa como Moráceas (mora blanca y negra), Ciperaceas (cebollín), Solanaceas (Datura, tabaquillos, tutías, pimientos y ajies, tomates), algunas Crucíferas (colza), Fabáceas o Leguminosas (trébol blanco de olor (Melilotus albus), albizia (Albizia lebbeck), leucaena (Leucaena leucocephala) -exóticas; aromito (Acacia caven), vinal (Leucaena leucocephala) e itín (Prosopis kuntzei Harms)- vernáculas) y Poáceas: p.e. el sorgo de Alepo o pasto ruso (Sorghum halepense (L.) Persoon) maleza dispersada junto con granos o semillas para la siembra contaminadas con sus simientes y por los equipos de cosecha, ya que muchas semillas pueden "viajar" largas distancias desde el sitio original en todo el equipo de cosecha (sinfines, volquetes, carros tolvas y vehículos complementarios), los que pueden inclusive alojar semillas en la banda de rodamiento de sus neumáticos, ídem con los transportes que movilizan granos hacia silos o fábricas).

3- Pueden germinar escalonadamente en largos periodos de tiempo, lo que ayuda a su supervivencia tras catástrofes ocasionales.

4- La germinación de algunas especies está sincronizada con la del cultivo comensal, e incluso puede adelantarse unos días a éste. De este modo, colonizan antes el terreno. Los rasgos 1-4 son estrategias de dispersión temporal y espacial.

5- La producción de semillas es muy elevada, una típica estrategia de tipo "r". Pueden competir con el cultivo gracias a su elevado número. Además presentan con frecuencia otros órganos de propagación vegetativa (estolones, raíces gemíferas, rizomas, bulbos, tubérculos), que favorecen la invasión de nuevos hábitats, o su rebrote. Este es el caso de las Poaceae y Cyperaceae muy comunes en estos ambientes.

6- Su variabilidad genética es muy grande, lo que aumenta la posibilidad de que algunos individuos sobrevivan a cambios adversos (lo que explica la aparición de resistencias a herbicidas).

7- Su morfología y fisiología las hace ser más competitivas que las cultivadas: raíces más tupidas, follaje más denso por ejemplo el pasto estrella africano (Cynodon plectostachium), pata de perdiz (Cynodon dactylon (L.) Person), pata de gallina (Eleusine tristachya), pasto chato o pasto jesuita (Axonopus compressus), o bien emisión de compuestos químicos perjudiciales para otras plantas (alelopatía), p.e. botón de oro (Galinsoga parviflora Cav.).

No obstante, adhiriéndonos a lo expresado por Ana Ortega Olivencia et al. (1983) aunque sólo se las censura por su carácter nocivo, cumplen -como otras plantas- funciones valiosas en la naturaleza. Entre ellas están:

- Disminuir la erosión del suelo en tierras abandonadas.

- Añadir materia orgánica al suelo.

- Proporcionar alimento y refugio a la fauna silvestre y/o ganado.

- Producir sustancias medicinales útiles o comidas exquisitas.

- Embellecer el paisaje.

Publicado en formato digital: Prof. Juan Antonio Alberto. EXPANSIÓN URBANA, PARANTROFITIA Y PARANTROZOOTIA... ¿BIOCENOSIS ANTROPOGÉNICAS? EL CASO DEL ÁREA METROPOLITANA DEL GRAN RESISTENCIA (A.M.G.R.), CHACO. Revista Geográfica Digital. IGUNNE. Facultad de Humanidades. UNNE. Año 11. No 22. Julio - Diciembre. 2014. ISSN 1668-5180 Resistencia, Chaco.

En: http://hum.unne.edu.ar/revistas/geoweb/default.htm 
- Pueden ser bioindicadoras por su comportamiento eco-fisiológico de determinados aspectos. Así, pueden tener valor indicativo de las cualidades del suelo, por ejemplo, acerca del contenido en fósforo, potasio, nitrógeno y humus. En ocasiones pueden indicar el grado de humedad de una determinada estación. Por ejemplo, en nuestro caso la ortiga común (Urtica urens), es indicadora de suelos ricos en nitrógeno, propio de corrales, piquetes y gallineros abandonados - como así mismo en los activos, donde se dan en sus bordes no pisoteados y áreas próximas a estos.

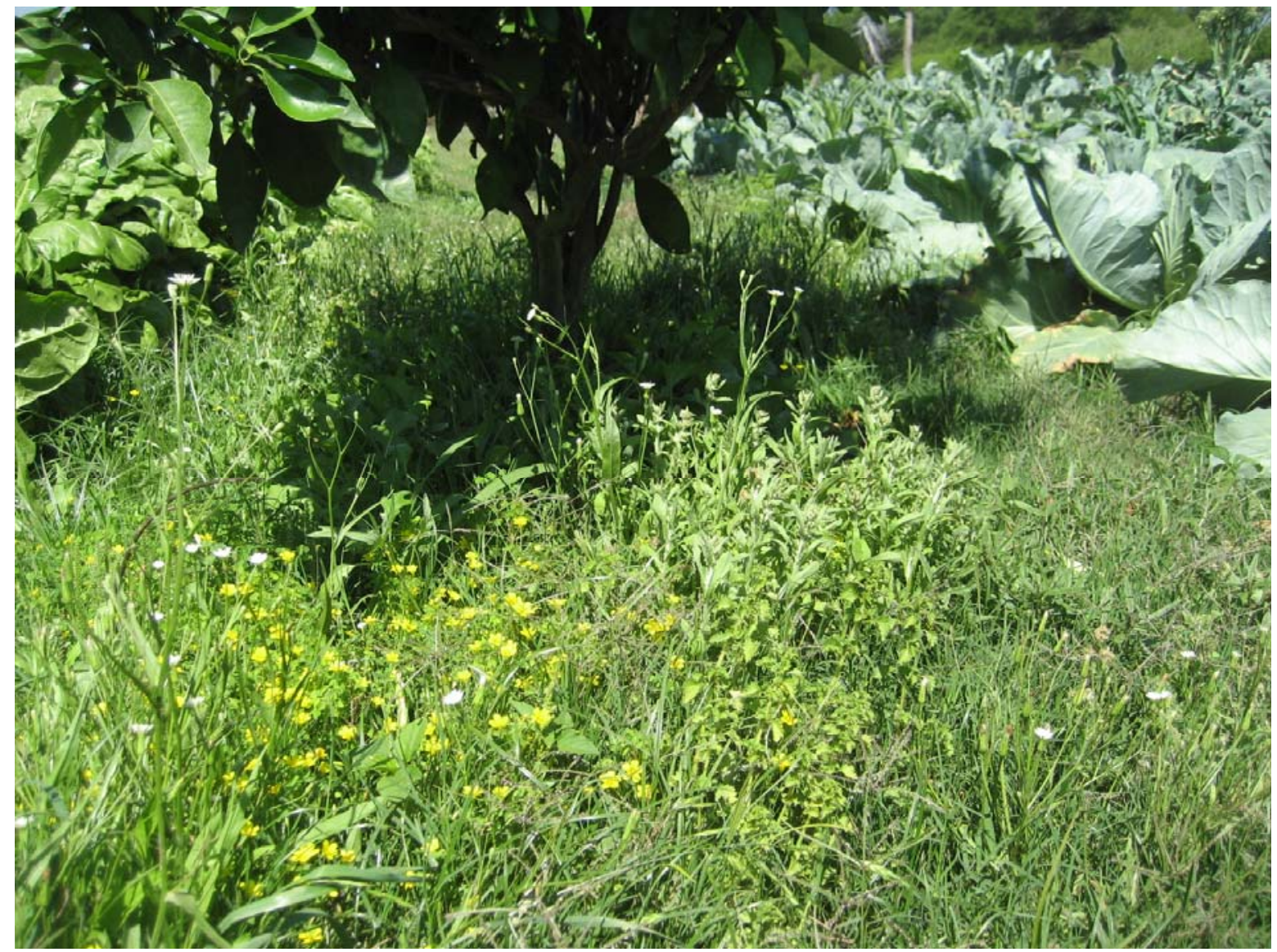

Fig. 5 .Comunidad arvense, grupo de plantas que crecen en forma espontánea en terrenos cultivados, favorecidas por las prácticas que el hombre realiza. En la foto Hypochaeris chilensis (flores blancas), vinagrillo o macachin (Oxalis sp.) -flores amarillas, pata de perdiz (Cynodon dactylon), cebollín (Cyperus rotundus), hierba mansa o peludilla (Gamochaeta coarctata (Willd.) Kerguélen)y ortiga chica (Urtica urens) -en el centro, asociadas a cultivos de repollos, acelgas y cítricos. Paraje El Tropezón. Resistencia Norte.

Más allá del calificativo de plagas -algunas lo son- si nos remitimos a la composición florística de estos ambientes y el origen de las plantas que los componen, se observa una coexistencia de nativas y exóticas eurioicas, cosmopolitas, variando la proporción de unas y otras según las zonas. Cerca de la ciudad, ambientes rururbanos y agrosistemas tienden a aumentar la presencias de exóticas asociadas a las actividades humanas, mientras en lindes con ámbitos naturales (bosques, pastizales, esteros, red hidrográficas) predominan las especies nativas pioneras o colonizantes que tienden a cicatrizar claros y barbechos dejados por el hombre. Del mismo modo se dan en corredores y en ámbitos rurales, rururbanos y vorurbanos, próximo a la actividad o movimiento humano aumentan las frecuencias de exóticas y adventicias, mientras hacia ambientes naturales con poco impacto TROZOOTIA... ¿BIOCENOSIS ANTROPOGÉNICAS? EL CASO DEL ÁREA METROPOLITANA DEL GRAN RESISTENCIA (A.M.G.R.), CHACO. Revista Geográfica Digital. IGUNNE. Facultad de Humanidades. UNNE. Año 11. № 22. Julio - Diciembre. 2014. ISSN 1668-5180 Resistencia, Chaco. 
humano se dan las nativas, especialmente las con mayor amplitud ecológica, en general colonizantes, sobre los límites se dan ecotonos o los efectos de borde. Los efectos de borde son las diferencias que percibimos, por ejemplo en las orillas de los bosques o de una laguna y el espacio circundante debido a las variaciones en la composición, estructura y función de sus componentes, debido a que son distintas las condiciones edáficas, topográficas y su microclima (viento, temperatura y humedad), entremezclándose especies de uno y otro ambiente, pues por lo indicado corresponden a zonas de tensión y dinamismo por continuos cambios.

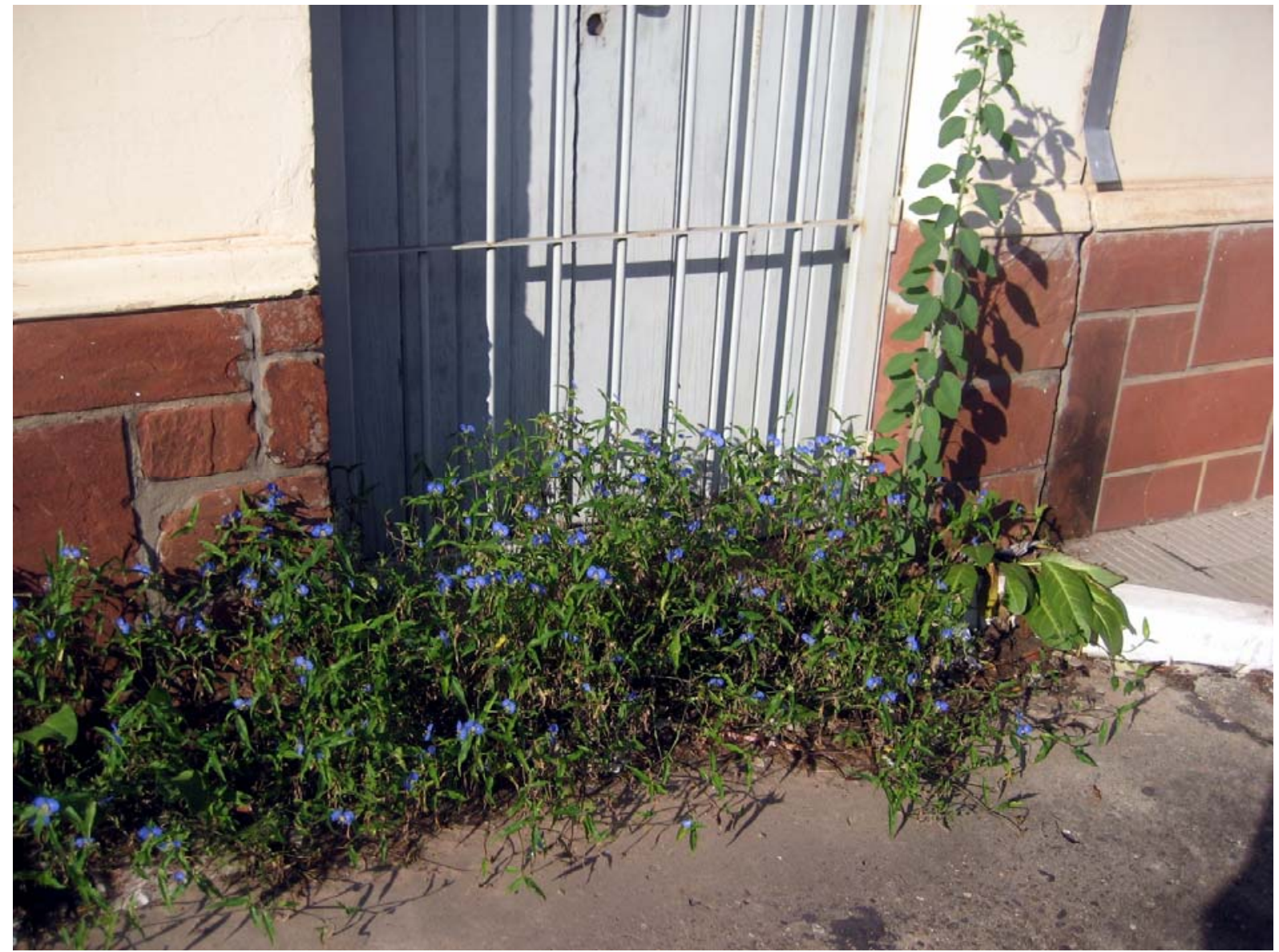

Fig.6 .Comunidad ruderal, grupo de plantas que crecen en forma espontánea en medios creados por los asentamientos humanos (escombros, muros, calles, veredas, baldíos, tejados, vertederos). En esta foto población de Santa Lucía (Commelina erecta), palán palán (Nicotiana glauca Gram.) y flor del sapo (Jaborosa integrifolia) en una vereda y estacionamiento del Campus Resistencia, UNNE.

En cuanto a la distribución espacial de las poblaciones que conforman estas biocenosis antropogénicas, varía en relación con las especies y/o familias dominantes e interacciones entre organismos (competencia, alelopatía, colonización proximal, etc.), como también a factores del biotopo (luz, agua, pH, bacidez, riqueza en nutrientes, microrelieves, etc.), ya que la distribuciones no aleatorias de cualquier tipo de organismo es la norma, más que la excepción, tanto en ecosistemas terrestres como acuáticos (Rossi 2003, Crist 1998, Maestre et al. 2005a, Barnes et al. 2007 citados por Maestre y Escudero 2008); en efecto a una escala que abarque un gran espacio (parque, chacra, camino, laguna) y un hábitat amplio (bosque, pastizal, arbustal), las poblaciones que en él viven interaccionan entre ellas y con el medio, lo cual origina distribuciones espaciales de estas que, además de no ser TROZOOTIA... ¿BIOCENOSIS ANTROPOGÉNICAS? EL CASO DEL ÁREA METROPOLITANA DEL GRAN RESISTENCIA (A.M.G.R.), CHACO. Revista Geográfica Digital. IGUNNE. Facultad de Humanidades. UNNE. Año 11. № 22. Julio - Diciembre. 2014. ISSN 1668-5180 Resistencia, Chaco. 
homogéneas cambian con el tiempo, más en estos ámbitos antropogénicos (urbanos, suburbanos, vorurbanos, rururbanos, rurales y viales) por su dinamismo lógico. En líneas generales, desde el punto de vista paisajístico pueden darse:

1. Distribución separada (distanciada), individual o en conjunto de individuos autónomos, independientes - amacollados, arrosetados- (organización al azar y agregada o agrupada), formando matas o pastizales uniformes a la vista, con composición homogénea o monoespecífica (una sola especie) o heterogénea o poliespecífica (varias especies). Por ej. Herbáceas solas o en mata: -en huertas, patios, veredas, banquinas, baldíos urbanos y periurbanos: Cebadilla criolla o australiana (Bromus catharticus), diente de león (Taraxacum), llantén (Plantago sp.), cola de gama (Heliotropium amplexicaule Vahl.), amor seco (Bidens pilosa), yerba de pollo (Alternanthera pungens Kunth), yerba de la golondrina (Euphorbia serpens Kunth), yerba lucero (Pluchea sagittalis (Lam.) Cabrera), paico (Chenopodium ambrosioides), parietaria (Parietaria officinalis), rompe piedra (Phyllanthus niruri), cadillos (Cenchrus), abrojos (Xanthium); -en zanjas, cunetas y bajos: pasto bolita (Cyperus), escleria (Scleria $s p$.), cleome (Cleome), Catay colorado (Polygonum punctatum Elliot); escandentes: mburucuyá (principalmente Passiflora caerulea L. y Passiflora foetida L. foetida), ojos de muñeca o isipó morotí (Paullinia elegans), tasis o docas (Morrenia odorata y Funastrum clausum), barba de viejo, tuyá-rendivá o cabello de ángel (Clematis montevidensis Spr.), porotos silvestres (Vicia macrograminea); cespitosas: pata de gallo o zacate egipcio (Dactyloctenium aegyptium (L.) Willd.). Ejemplos visibles en ámbitos urbanos y periurbanos con mezclas de nativas y exóticas o adventicias, en ambientes viales (banquinas y ensanches de rutas), ruderales (baldíos, barbechos, patios, terrazas, techos, veredas, campus y estacionamientos), arvenses (huertas, chacras, quintas, barbechos rurales y franjas adyacentes) y obviamente en ambientes naturales próximos y lindantes a los antrópicos citados. Vale aclararse para el caso de poáceas y ciperáceas, que en terrenos planos, bajos, en algunos parajes denominados "cangrejales" (dada la presencia de estos animales), las plantas a simple vista aparecen como pastizales uniformes o en manchones, pero confieren al suelo una superficie irregular, como una botonera de teléfono o motas que alojan sus sistemas radiculares, bulbos y rizomas, dificultando el desplazamiento y entre las cuales se acumula el agua en épocas lluviosas o fango al evaporare e infiltrarse esta, permitiendo la aparición esporádica de gramillas y plantas acuáticas de pequeño porte, como por ejemplo el pastito de agua (Luziola peruviana), estrellita de agua (Nynphoides indica), pontederia (Pontederia cordata), Sagitarias (Sagitaria montevidensis y S. rhombifolia) y dos bellas plantas: Hydrolea elatior y Justicia laevilinguis, que merecen cultivarse en jardines acuáticos; mientras en épocas secas, este suelo se cementa y endurece. Para este tipo de distribución tenemos como ejemplos: en cañadas o superficies bajas inundables estacionalmente: paja boba (Paspalum intermedium) y paja colorada (Paspalum quadrifarium) acompañadas varias especies de Ciperáceas (Cyperus esculentus, Rhynchospora corymbosa, Oxycarium cubense, ) cuyas poblaciones muchas veces dominan sobre las Poáceas el terreno inundado; en tramos menos inundables: paja amarilla (Sorghastrum setosum), Paja estalladora (Saccharum angustifolium=Eryanthus angustifolius); en terrenos planos altos con suelos más fértiles: espartillo (Elionurus muticus), cola de zorro (Schizachyrium condensatum); bordeando ambientes bajos y cunetas: pasto macho o paja boba (Paspalum urvillei), paja de plata o pasto penacho blanco (Deyeuxia viridi-flavescens = Calamagrostis montevidensis). Fig.6.

Publicado en formato digital: Prof. Juan Antonio Alberto. EXPANSIÓN URBANA, PARANTROFITIA Y PARANTROZOOTIA... ¿BIOCENOSIS ANTROPOGÉNICAS? EL CASO DEL ÁREA METROPOLITANA DEL GRAN RESISTENCIA (A.M.G.R.), CHACO. Revista Geográfica Digital. IGUNNE. Facultad de Humanidades. UNNE. Año 11. № 22. Julio - Diciembre. 2014. ISSN 1668-5180 Resistencia, Chaco.

En: http://hum.unne.edu.ar/revistas/geoweb/default.htm 
2. Distribución agregada continua (encadenada), monoespecífica o con predominio de una especie, regular de tapiz prolongado uniforme, o irregular de tapiz discontinuo homogéneo (cubierta entrecortada o manchones), por irradiación de ramificaciones de tallos secundarios rampantes, rastreros o subterráneos, p.ej. en general la mayoría de las Poáceas o Gramineas de crecimiento cespitoso como, pasto miel (Paspalum dilatatum), gramilla blanca o pasto horqueta (Paspalum notatum Flueg.), pasto estrella africano (Cynodon plectostachium), pata de perdiz (Cynodon dactylon (L.) Person), pata de gallina (Eleusine tristachya), pasto chato o pasto jesuita (Axonopus compressus).

A su vez distribuidas en forma:

A- Lineal irregular, propagándose mas en largo y/o alto que en ancho, por ejemplo siguiendo cunetas, zanjas, canales como achiras (Cannáceas), cucharero, ciperáceas, poáceas higrófias (Echinochloa crus-pavonis (Kunth) Schult); escandentes o trepadoras sobre alambrados, cercos y muros como: campanillas (Ipomea varias especies), dama de noche (Ipomea alba L.), teyú isipó o clarinete (Dolichandra cynanchoides Cham.); pastizales o malezales en banquinas y terraplenes: sorgo de Alepo o pasto ruso (Sorghum halepense (L.) Persoon.), trébol blanco de olor (Melilotus albus), malvisco o malvavisco (Sphaeralcea bonariensis). Fig.7.

B- Espacial, irradiándose en todos los sentidos proporcionalmente, enlazadas como una red, cubriendo áreas más o menos importantes, por ejemplo en represas, charcas y lagunas: camalotes (Eichornia), repollitos (Pistia stratiotes) y lentejas de agua (Lemma); en esteros y represas grandes: achiras (Canna), totoras (Tipha) y juncos (Scirpus californicus); en terrenos altos pasto horqueta o bahía (Paspalum notatum), pasto miel (Paspalum dilatatum); en baldíos y patios umbrosos o media sombra: oreja de gato (Dichondra repens var. Microcalyx), tréboles o macachines (Oxalis selloviana y otras), parietaria ( ).

3. Distribución regular alineada artificial (plantaciones hechas por el hombre), p.ej. pinos, eucaliptos (Eucaliptus varias especies), ligustros (Ligutrum lucidum), ligustrinas (Ligustrum sinense), grebileas o robles sedosos (Grevilea robusta), álamos (Populus alba y otras), etc.

- En lo referente a las fisonomías y composición florística, considerando las bioformas de Raunkiaer, se observa dos grandes predominios, las hemicriptófitas rastreras, cespitosas o en macollos, o bien arrosetadas, seguidas por criptófitas (geofitas y helófitas, e hidrófilas en ambientes acuáticos), acompañadas en menor proporción por las terófitas y caméfitas, mientras es muy menguada la presencia de fanerófitas arbóreas, salvo aquellas seleccionadas por el hombre cerca de alambrados, cercos y caminos como sombra y ornamento o las existentes en viejos jardines abandonados; sí dentro de este grupo tienen presencia las fanerófitas arbustivas (géneros Acacia y Prospis) y escandentes (géneros Bignonia e Ipomea), no obstante su mayor o menor manifestación depende de la intervención humana. Mientras en lo referente a la taxonomía o composición florística se ve un dominio de las Poáceas o Gramíneas y las Asteráceas o Compuestas, seguidas por las Solanáceas y Malváceas, variando en todos los casos los géneros según las comunidades donde prosperan (arvenses, ruderales y viales), por otro lado en algunos ambientes específicos dominan las Urticáceas, asociadas a algunos géneros de las Asteráceas y Solanáceas, en especial nitrófilas (típicas de antiguos corrales y sus adyacencias, huertas y quintas que usan tierras de corrales para abono), en otros ámbitos forman tapices irregulares y matas las Verbenáceas (géneros Verbena, Glandularia y Phyla), o se agrupan en manchones edáficos (suelos salinos, alcalinos) prosperando ciertas Borragináceas (Heliotropium indicum L., $H$. aplexicaule y H. curassavicum).

Publicado en formato digital: Prof. Juan Antonio Alberto. EXPANSIÓN URBANA, PARANTROFITIA Y PARANTROZOOTIA... ¿BIOCENOSIS ANTROPOGÉNICAS? EL CASO DEL ÁREA METROPOLITANA DEL GRAN RESISTENCIA (A.M.G.R.), CHACO. Revista Geográfica Digital. IGUNNE. Facultad de Humanidades. UNNE. Año 11. No 22. Julio - Diciembre. 2014. ISSN 1668-5180 Resistencia, Chaco.

En: http://hum.unne.edu.ar/revistas/geoweb/default.htm 


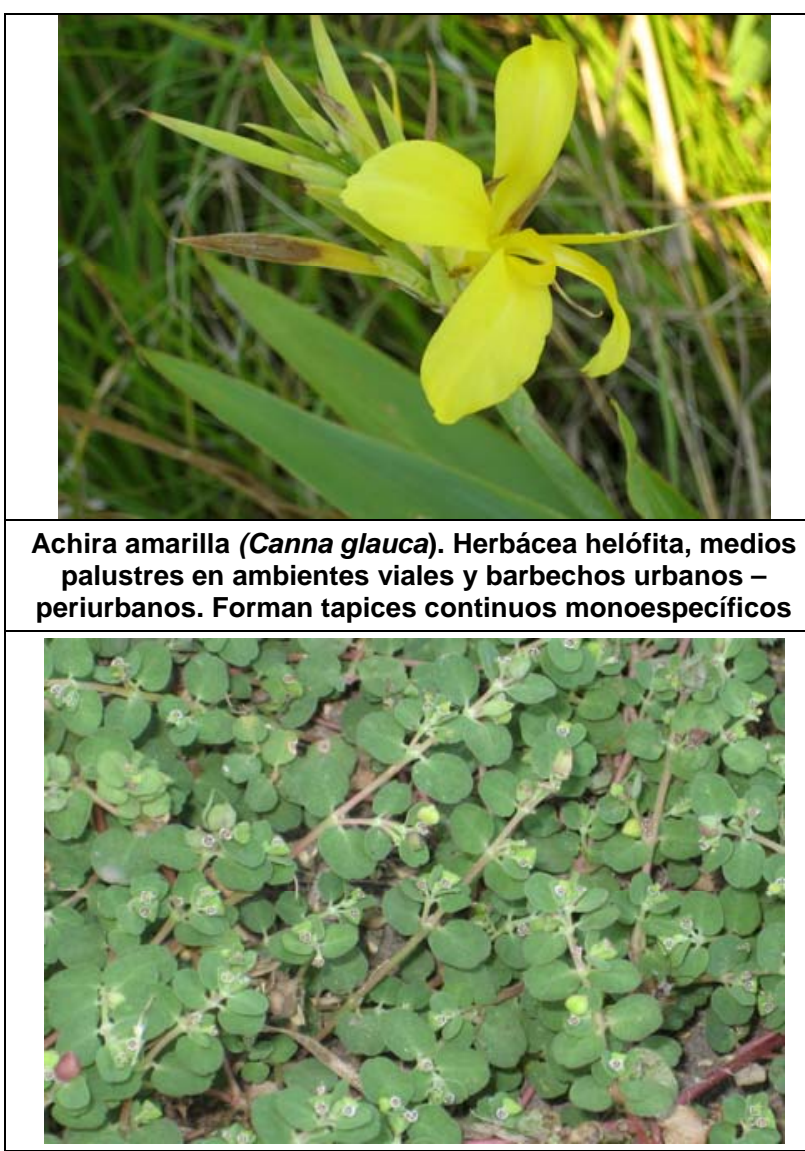

Yerba de la golondrina (Euphorbia serpens H.B.K.). Herbácea rampante, tapiz prolongado uniforme o en manchones. Ambientes ruderales y ocasionalmente en espacios viales

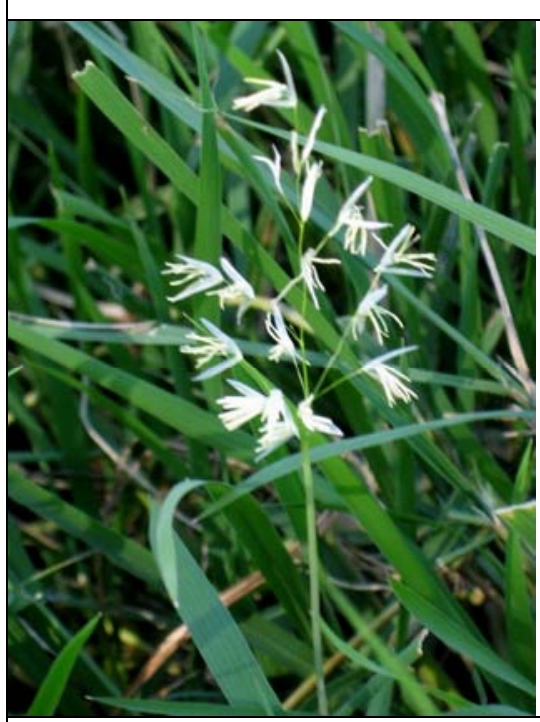

Pastito de agua (Luziola peruviana) terrenos bajos y bordes de charcas, entre matas de ciperáceas y otras poáceas higrófilas

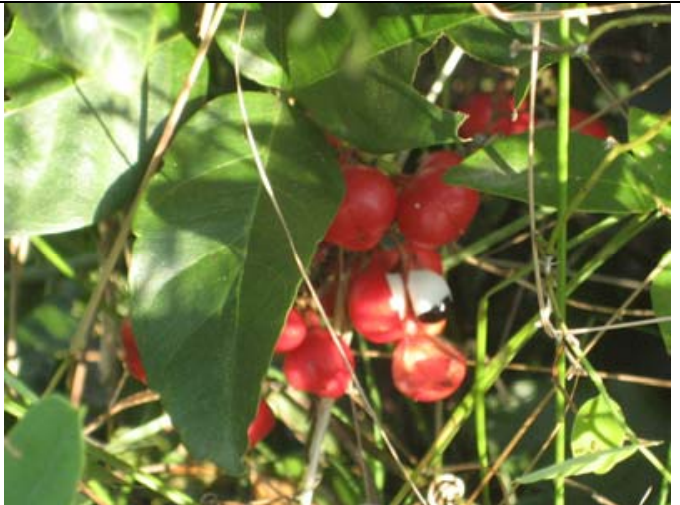

Ojos de muñeca o isipó morotí (Paullinia elegans). Trepadora, sobre alambrados, cercos, y fanerófitas de comunidades viales y barbechos urbanos - periurbanos

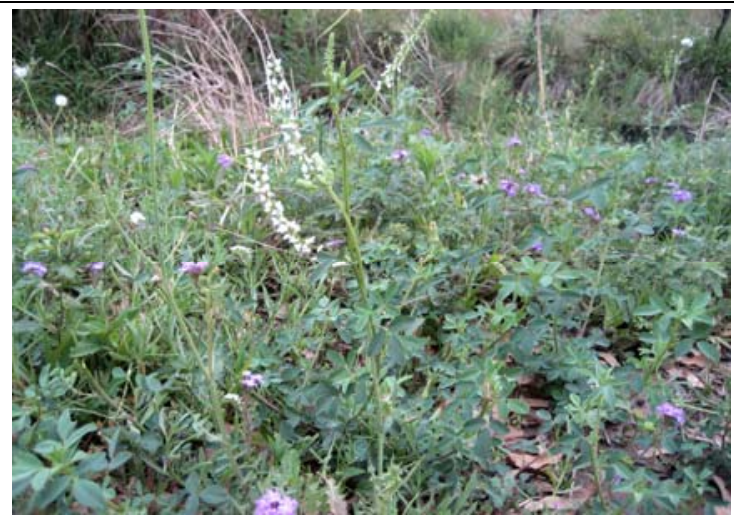

Trébol blanco de olor (Melilotus albus Medik. Fabaceae) en comunidades viales (márgenes de caminos y terraplenes de rutas), en cabeceras y límites de chacras y campos de pastoreo. Comunidades arvenses y ruderales

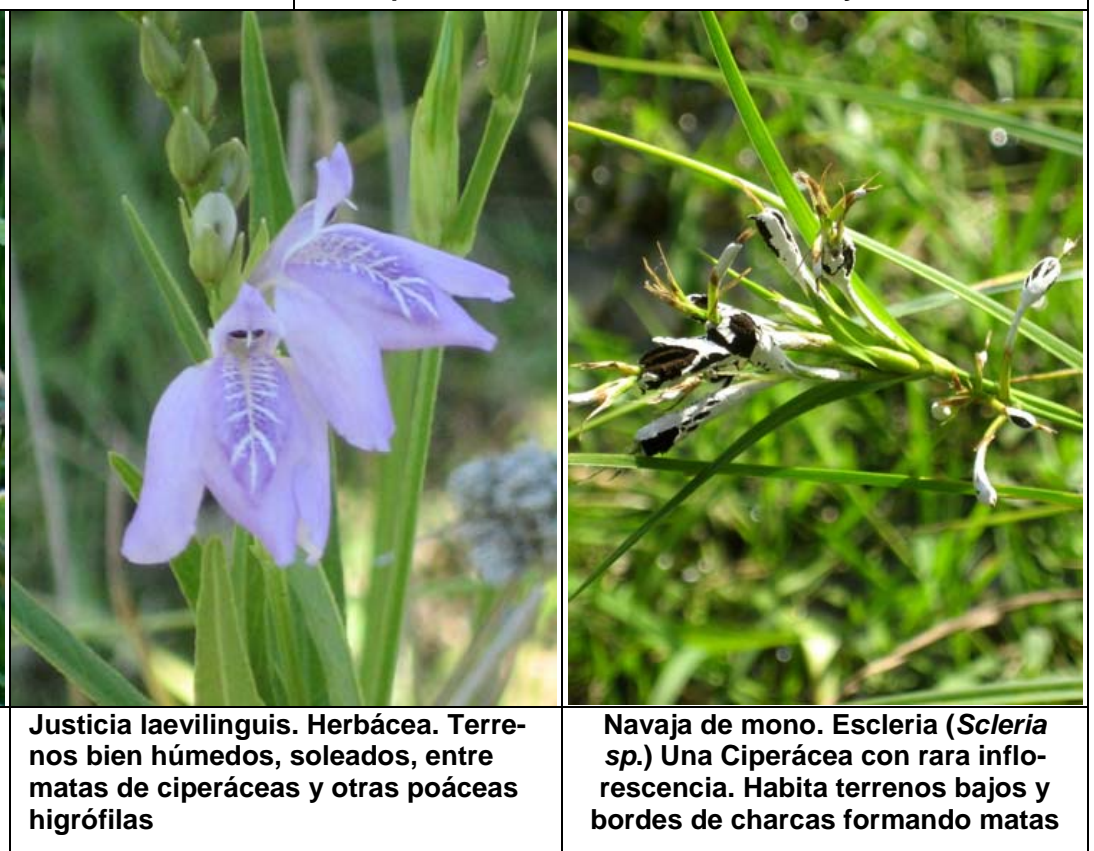

Fig. 7. Plantas que conforman los paisajes periurbanos con distintos tipos de distribución, comunidades y ambientes.

Publicado en formato digital: Prof. Juan Antonio Alberto. EXPANSIÓN URBANA, PARANTROFITIA Y PARANTROZOOTIA... ¿BIOCENOSIS ANTROPOGÉNICAS? EL CASO DEL ÁREA METROPOLITANA DEL GRAN RESISTENCIA (A.M.G.R.), CHACO. Revista Geográfica Digital. IGUNNE. Facultad de Humanidades. UNNE. Año 11. № 22. Julio - Diciembre. 2014. ISSN 1668-5180 Resistencia, Chaco. 


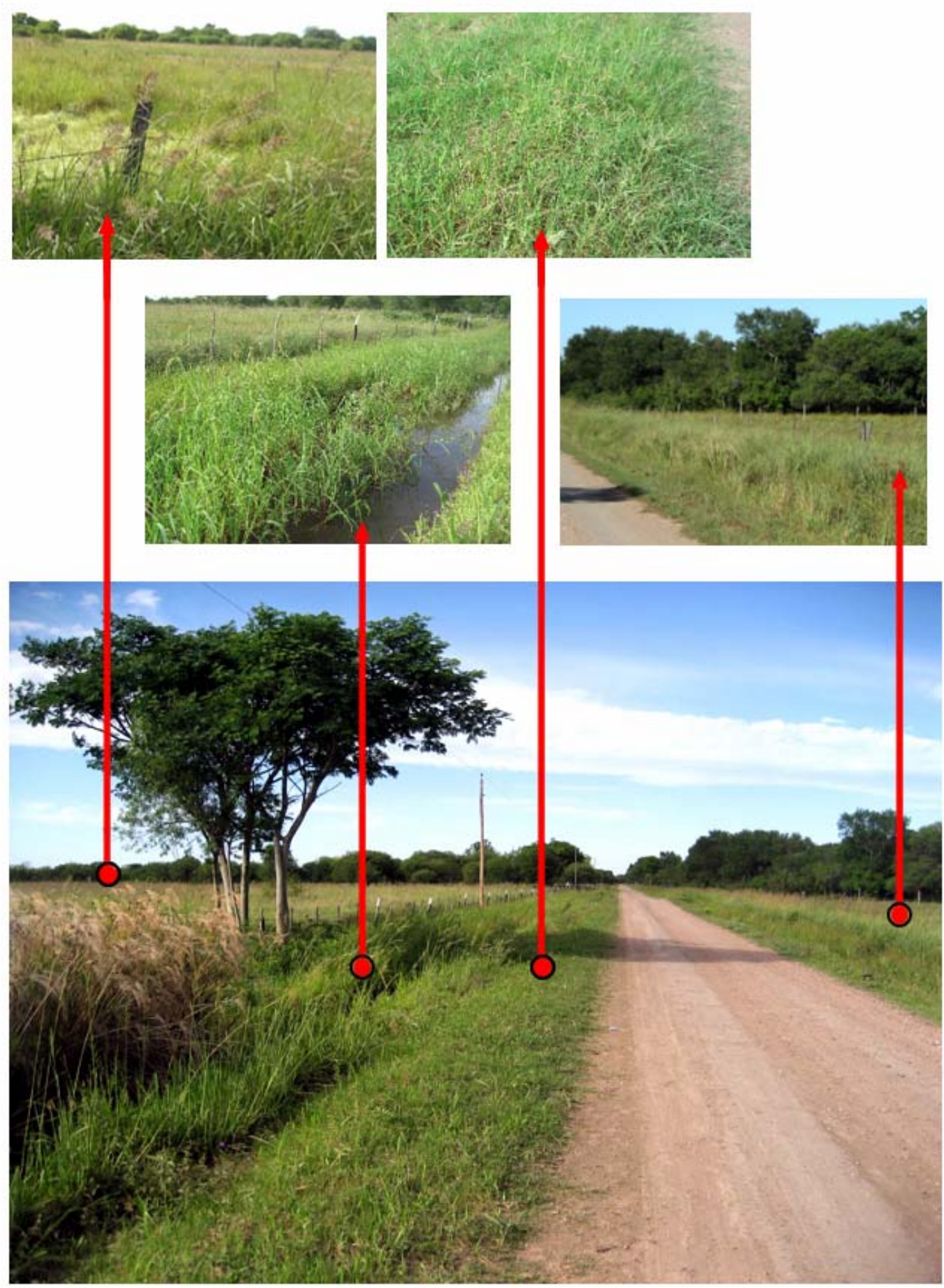

Fig.9. Comunidad vial o viaria sobre camino primario de tierra con sus banquinas, zanjas o cunetas y alambrados. Las fitocenosis varían desde las banquinas hasta los límites de los predios contiguos, predominando en general herbácea, en especial las Poáceas o Gramíneas de tipo cespitoso en banquinas y bordes de la calle (exóticas o adventicias con más frecuencia), amacolladas erectas en cunetas, líneas de alambrados y campos vecinos (poáceas nativas comúnmente). Ambiente muy dinámico dado que el espacio vial público es frecuentemente intervenido con mantenimientos. Foto Resistencia Norte- Acceso antiguo a Colonia Benítez.

Publicado en formato digital: Prof. Juan Antonio Alberto. EXPANSIÓN URBANA, PARANTROFITIA Y PARANTROZOOTIA... ¿BIOCENOSIS ANTROPOGÉNICAS? EL CASO DEL ÁREA METROPOLITANA DEL GRAN RESISTENCIA (A.M.G.R.), CHACO. Revista Geográfica Digital. IGUNNE. Facultad de Humanidades. UNNE. Año 11. No 22. Julio - Diciembre. 2014. ISSN 1668-5180 Resistencia, Chaco. 
En lo referente a la distribución en el tiempo y los ciclos estacionales, se observa que al promediar el invierno (incluso durante éste si no es muy riguroso) comienzan su desarrollo aéreo muchas herbáceas arrosetadas y en macollo, predominando las Asteráceas o Compuetas (Géneros: Sonchus, Scolymus, Cirsium, Taraxacum, Gamochaeta, Hypochoeris, ), Solanáceas (Nicotiana, Solanum, Jaborosa), Fabáceas (Melilotus, Vicia, Vignia), Brasicáceas (Brassica), Plantagináceas (Plantago), Calyceráceas (Acicarpha) y Oxalidáceas (Oxalis: vinagrillos, macachines o tréboles amarillos y rosados) que pasan a fructificación durante la primavera y reposo al comenzar el verano; en tanto al promediar la primavera y comenzar el estío adquieren gran desarrollo las Poaceas o Gramíneas heliófilas,en especial las cespitosas y en macollo por ejemplo los Géneros: Andropogon, Axonopus, Chloris, Cenchrus, Cynodon, Digitaria, Echinochloa, Eleusine, Eragrostis, Hymenachne, Leptochloa, Panicum, Paspalum, Setaria, Sorghum con distintos ciclos de floración y fructificación, siguiendo en importancia algunos géneros de Asteráceas, en especial de tipo sufruticoso y terófitas altas como Bidens, Baccharis, Chromolaena, Eupatorium, Parthenium, Pterocaulon, Solidago, Tagete, Xanthium, también continúan creciendo las Solanáceas (Petunia, Capsicum, Cestrum, Datura, Salpichroa), acompañadas por otras familias frecuentes en estos ambientes, como Cyperáceas (Cyperus, Eleocharis, Rhynchospora, Scleria), Fabáceas (arbustivas, arbóreas: Acacia, Prosopis; herbáceas, sufruticosas, escandentes: Melilotus, Sena, Vicia, Vignia), Malváceas (Abutilon, Hibiscus, Pavonia, Sida, Sphaeralcea) Amarantáceas (Gomphrena, Alternanathera), Verbenáceas (Gladularia, Aloysia, Lantana, Verbena), Borragináceas (Heliotropium, Borago, Cordia), Rubiáceas (Galium, Richardsonia), Euphorbiáceas (Croton, Euphorbia) que forman verdaderos floridos vergeles, multicolores y aromáticos, de las cuales muchas especies deberían ser valoradas como ornamentales a la hora de diseñar jardines y parques con visión ecológica y sustentable (Figs. 8, 9 y 10). Es interesante observar y registrar los ciclos evolutivos de estas plantas - sobre todo floración y dispersión de semillas-, en especial Poáceas y Asteráceas -que son las más numerosas, ya que muchas son alérgenas, sea por su polen abundante o por sus semillas provistas en muchos casos de papus o vilanos y algodones, siendo esto motivo de las conocidas molestias de origen alérgico como las incomodidades respiratorias, dermatitis, irritaciones de ojos y oídos, tanto en personas como en animales.

Obviamente esta vegetación aloja y se relaciona con una fauna también peculiar, la que conforma zoocenosis vinculadas, directa o indirectamente, a los grupos humanos, a la sazón podemos hablar de parantrozootia, es decir de comunidades animales propias de ambientes alterados por el hombre, que habitan las fitocenosis -antes analizadas- creadas 0 alteradas por acción antrópica. Al respecto, siguiendo a Marcela Alejandra Sierra Vásquez (2012), consideramos que teniendo en cuenta la estructura propia del entorno urbano, la fauna afronta escenarios hostiles dentro de este entorno, dada la fragmentación de su hábitat, la contaminación, el ruido, la ausencia de espacios apropiados, la artificialidad del mosaico urbano, la falta de agua y alimento, el tránsito de vehículos, entre otras. Estos factores restringen la hospitalidad del entorno urbano para los animales, razón por la cual se hace necesario visualizar las problemáticas, que más determinan su subsistencia en la ciudad, como son:

- Crecimiento rápido y desordenado de las áreas urbanas.

- Alteración de las cuencas, contaminación y desaparición de ecosistemas acuáticos.

- Aislamiento de fragmentos verdes, reducidos en tamaño y con alto grado de manejo.

- Actitudes sociales negativas, relacionadas con el temor, la superstición, la cultura de la exterminación, desconociendo su función e importancia ecológica. Es decir no todos los animales silvestres son bien admitidos, atendidos o aceptados por la sociedad, y debido

Publicado en formato digital: Prof. Juan Antonio Alberto. EXPANSIÓN URBANA, PARANTROFITIA Y PARANTROZOOTIA... ¿BIOCENOSIS ANTROPOGÉNICAS? EL CASO DEL ÁREA METROPOLITANA DEL GRAN RESISTENCIA (A.M.G.R.), CHACO. Revista Geográfica Digital. IGUNNE. Facultad de Humanidades. UNNE. Año 11. № 22. Julio - Diciembre. 2014. ISSN 1668-5180 Resistencia, Chaco.

En: http://hum.unne.edu.ar/revistas/geoweb/default.htm 
a ignorancia, mala información o incluso creencias culturales, como el caso de serpientes, sapos, murciélagos, búhos y comadrejas que son corrientemente ahuyentados 0 perseguidos debido a sus hábitos nocturnos, creando recelos infundados. Lo cierto es que la existencia de este tipo de fauna, aporta múltiples provechos como el caso de las lechuzas que han cambiado su dieta a la oferta nocturna urbana, comiendo cucarachas, ratas y ratones, los cuales son plagas provenientes de la gran cantidad de desechos generados en la ciudad.

A esta fauna urbana y periurbana vinculada al hombre, ya sea como animales en forma individual o conformando zoocenosis antropizadas podemos catalogarlos en los siguientes grupos, según sus hábitos y vinculaciones con los humanos:

- Animales domésticos vagabundos, inicialmente gregarios pero dejados a su suerte por abandono y malos tratos, adquieren conductas semisalvajes, agresivas, son portadores de virus y transmisores de distintas zoonosis (rabia, parasitosis varias -endo y exoparasitismos-, taxoplasmosis, lesmaniasis, etc). Ejemplos: perros, gatos, cerdos, conejos, caballos.

- Animales silvestres domesticados como mascotas, que escapan y vuelven al entorno pero que ni se integran totalmente a la antropocenosis ni retoman totalmente sus condición de fauna vernácula por haber adquiridos hábitos alimentarios y conductuales vinculados a su condición de mascotas. Ejemplos: loros, cotorras, lagartos, paseriformes varias, zorros, conejos y liebres, gatos salvajes, osos hormigueros, coatíes y otros.

- Animales silvestres oportunistas, se acercan y asocian al hábitat humano (viviendas y dependencias) o sus infraestructuras vinculadas a sus tareas cotidianas (caminos y vías, fábricas, depósitos, tambos, gallineros, presas y represas, etc.), obteniendo en estos ámbitos alimentos y refugios fáciles. Ejemplos: iguanas, urracas, pilinchos, ipacaas, charata (Ortalis canicollis), ratoneras o tacuaritas (Troglodytes aedon), pitogüés (Pitangus sulphuratus) palomas: Picuies (Columbina picui picu), torcazas (Zenaida auriculata) y yeruties (Leptotila verreauxi), aves rapaces y carroñeras varias (caranchos, gavilanes, halcones, algunas estrígidas, jotes o zopilotes (Coragyps atratus), sapos, ranas, culebras y víboras constrictoras: ñacanina (Hidrodynastes gigas), y curiyú), vinchucas, moscas y mosquitos, hormigas, arañas y diversidad de avispas. En muchos de estos casos los mismos humanos creamos sus cambios de hábitos alimentarios y conductas, al ofrecerles alimentación extra o de fácil obtención, tales como comederos, bebederos, nectarios, etc. Acciones que nos acercan a la vida natural, pero que pueden tener efectos negativos en ella y su equilibrio, simplemente recordemos la importancia de cada organismo en los ciclos de vida, en la polinización, la dispersión, en las relaciones presa-predador y control biológico de las poblaciones ya sean de animales, vegetales o de microbios, situación muy bien planteada -y que nos sirve de ejemplo- en el trabajo de Orros, Melanie E. et al. (2014) referida a un estudio sobre la alimentación suplementaria de aves silvestres y su incidencia indirecta sobre las poblaciones de escarabajos de tierra en jardines suburbanos en el Reino Unido.

- Animales urbanos, exóticos ylo adventicios, aquella fauna y parásitos asociados que si bien no son intencionalmente criados por los humanos, fueron alguna vez introducidos por ellos y que regularmente viven en la ciudad y sus adyacencias. Ejemplos: Paloma doméstica (Columba livia), gorriones (Passer domesticus), ratas y ratones, pulgas, ácaros, cucarachas.

- Animales domésticos y silvestres domesticados que cohabitan con los seres humanos, todos aquellos animales que no integran los grupos anteriores y que individualmente o en pequeños grupos viven en viviendas y sus dependencias, por ejemplo TROZOOTIA... ¿BIOCENOSIS ANTROPOGÉNICAS? EL CASO DEL ÁREA METROPOLITANA DEL GRAN RESISTENCIA (A.M.G.R.), CHACO. Revista Geográfica Digital. IGUNNE. Facultad de Humanidades. UNNE. Año 11. No 22. Julio - Diciembre. 2014. ISSN 1668-5180 Resistencia, Chaco. 
gatos, perros, hamsters, conejos, cobayos, tortugas, lagartos, canarios, periquitos australianos y otras psitácidas, etc.

Según Mc Kinney 2006, Olden et al. 2006, la composición de las comunidades (aves, insectos, mamíferos y plantas) que viven en ambientes urbanizados tiende a simplificarse y homogeneizarse. A la vez que las especies exóticas se convierten en dominantes, a través de un proceso de pocos ganadores y muchos perdedores.
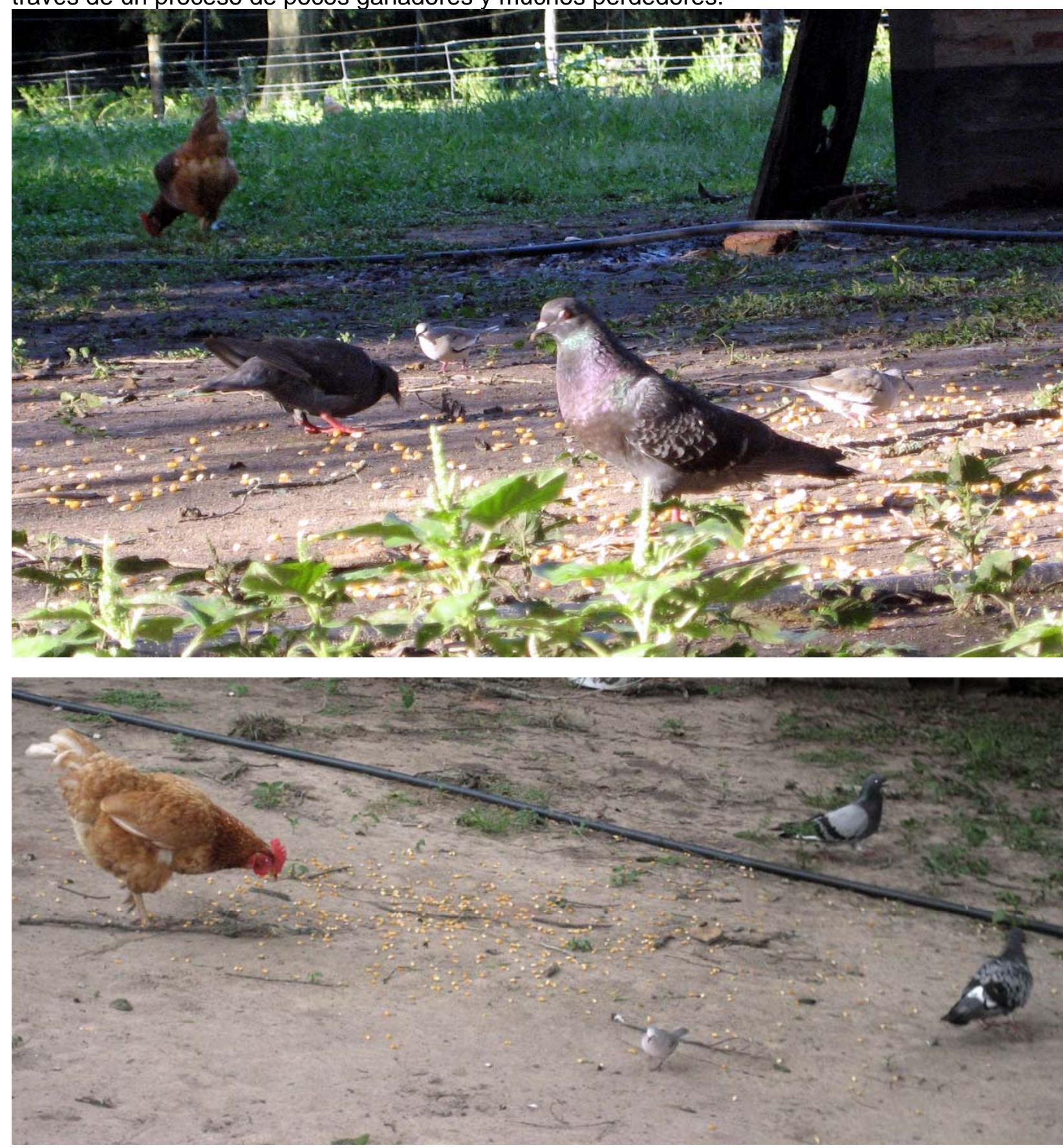

Fig. 3: Coexistencia e interacción de especies domésticas (gallinas), palomas domésticas (Columba livia, exóticas urbanas) y palomas silvestres (Picuí - Columbina picui) en una vivienda de ámbitos periurbano, ejemplos de parantrozootia

Publicado en formato digital: Prof. Juan Antonio Alberto. EXPANSIÓN URBANA, PARANTROFITIA Y PARANTROZOOTIA... ¿BIOCENOSIS ANTROPOGÉNICAS? EL CASO DEL ÁREA METROPOLITANA DEL GRAN RESISTENCIA (A.M.G.R.), CHACO. Revista Geográfica Digital. IGUNNE. Facultad de Humanidades. UNNE. Año 11. No 22. Julio - Diciembre. 2014. ISSN 1668-5180 Resistencia, Chaco.

En: http://hum.unne.edu.ar/revistas/geoweb/default.htm 


\section{CONCLUSIONES Y RECOMENDACIONES}

En base a lo analizado aquí, prestando atención a estos nuevos ambientes y sus paisajes como las biocenosis antropogénicas (ruderales, viales y arvenses) que lo habitan y configuran, hechos resultantes de los impactos de la expansión urbana, por ende de los distintos tipos y grados de intervención humana en la naturaleza, al observar y registrar la presencia, no regular y común, de un ejemplar o de una comunidad de determinada especie vegetal, animal y -porqué no- de microorganismos, debemos preguntarnos ¿Por qué, cómo y cuándo llegó aquí? ¿Qué permitió su arraigo y desarrollo o expansión? ¿Qué vínculos e interacciones tiene con la biota local? ¿A qué paisajes esta asociada? ¿Cuál es su impacto en los grupos humanos y el ambiente? ¿Qué problemas genera o puede suscitar en la dinámica ambiental y la calidad de vida del entorno, tanto natural como antropizado? y ¿Qué podemos hacer para valorizar sus impactos positivos o menguar/remediar sus efectos negativos? Al buscar respuestas a estos interrogantes tal vez podamos, fundamentar la presencia, ausencia o debilitamientos de determinados grupos de organismos antes frecuentes o comunes, explicar la existencia o propensión a ciertas incomodidades o malestares como alergias, asmas, dermatitis en humanos y en sus mascotas, justificar la aparición de ciertas plagas o alimañas, en definitiva demostrar los cambios en el ambiente y sus paisajes.

Sin dudas la existencia de plagas, la presencia de enfermedades o malestares recurrentes, incomodidades o perdidas tanto en lo humano como material y la calidad de vida de personas y del ambiente, son indicadores de un desarrollo nada sostenible, ya que el mismo se basa en la provisión de un lugar para vivir con una alta calidad de vida, segura y saludable, para la generación actual y para las futuras descendencias, protegiendo su entorno y la viabilidad de los sistemas naturales.

Entonces, según lo visto podemos concluir que estas nuevas biocenosis (fito, zoo y microcenosis) que dominan habitats y nichos ecológicos, transformados, abandonados 0 establecidos por los impactos de la antropocenosis urbana y periurbana (suburbana, rururbana, vorurbana y rural) se erigen en biocenosis antropogénicas y ecosistemas antropizados, ya que sus procesos, ciclos e interacciones son fuertemente injeridos por los grupos humanos y sus obras, al punto que su conformación y persistencias dependen en gran medida de estos, pues imprimen una nueva dinámica y fisonomías o paisajes consecuentes a estos ambientes, otrora naturales en el sentido estricto del concepto. En líneas generales, se pueden apuntar una serie de características peculiares que definen a cada comunidad y a los paisajes que ellas integran dentro del ámbito urbano y periurbano. Las cuales compendiamos en el siguiente cuadro:

\section{Algunas Características Frecuentes de Biocenosis Antropogénicas en el A.M.G.R.}

\begin{tabular}{|c|c|c|c|}
\hline Comunidades & Paisajes & Fitocenosis & Zoocenosis \\
\hline $\begin{array}{l}\text { Urbanas } \\
\text { Área edificada y sus } \\
\text { adyacencias. Espacios } \\
\text { verdes asociados. }\end{array}$ & Urbano, Suburbano & $\begin{array}{l}\text { Implantadas por el hombre. } \\
\text { Arbolado urbano y plantas } \\
\text { de jardines, balcones, terra- } \\
\text { zas, plazas, parques, vere- } \\
\text { das y parterres. Exóti- } \\
\text { cas/adventicias (árboles: } \\
\text { fresnos, álamos, chivatos, } \\
\text { albizias, falsas caobas, plá- } \\
\text { tanos, eucaliptos, grebileas, } \\
\text { farolito chino, tulipero de } \\
\text { Gabón. Herbáceas: vinca } \\
\text { per vinca, sanseviera, etc.) } \\
\text { Nativas regionales y extra- }\end{array}$ & $\begin{array}{l}\text { Introducidas conciente } \\
\text { inconcientemente por el } \\
\text { hombre. Distribución indivi- } \\
\text { dual o en grupos asociada a } \\
\text { espacios verdes y a depen- } \\
\text { dencias humanas (edificios, } \\
\text { infraestructura de servicios). } \\
\text { Animales exóticos y/o ad- } \\
\text { venticios (gorriones, palo- } \\
\text { mas domésticas, ratas, cu- } \\
\text { carachas, etc.); domésticos y } \\
\text { silvestres domesticados } \\
\text { (gatos, perros, conejos, }\end{array}$ \\
\hline
\end{tabular}

Publicado en formato digital: Prof. Juan Antonio Alberto. EXPANSIÓN URBANA, PARANTROFITIA Y PARANTROZOOTIA... ¿BIOCENOSIS ANTROPOGÉNICAS? EL CASO DEL ÁREA METROPOLITANA DEL GRAN RESISTENCIA (A.M.G.R.), CHACO. Revista Geográfica Digital. IGUNNE. Facultad de Humanidades. UNNE. Año 11. No 22. Julio - Diciembre. 2014. ISSN 1668-5180 Resistencia, Chaco.

En: http://hum.unne.edu.ar/revistas/geoweb/default.htm 


\begin{tabular}{|c|c|c|c|}
\hline & & $\begin{array}{l}\text { rregionales (árboles: lapa- } \\
\text { chos, palos borrachos, tipas, } \\
\text { jacaranda, viraró, cebil, ibirá } \\
\text { pitá. Epífitas: claveles del } \\
\text { aire, helechos y tunas, lí- } \\
\text { quenes. Escandentes. mbu- } \\
\text { rucuya, campanillas. Herbá- } \\
\text { ceas: achiras, rompe piedra, } \\
\text { lucera, oreja de gato, poá- } \\
\text { ceas varias, margarita pun- } \\
\text { zó, etc.) Distribución unifor- } \\
\text { me o regular, artificial, indivi- } \\
\text { dual o en grupos. }\end{array}$ & $\begin{array}{l}\text { hámster, psitácidas, paseri- } \\
\text { formes, etc.), silvestres opor- } \\
\text { tunistas (pitoués, cachilos, } \\
\text { tacuarita, lechuzas, cotorras, } \\
\text { jotes, caranchos, sapos, } \\
\text { ranas y lagartijas, avispas, } \\
\text { moscas y mosquitos) }\end{array}$ \\
\hline $\begin{array}{l}\text { Ruderales } \\
\text { Baldíos y todo sitio } \\
\text { alterado y descuidado } \\
\text { por el hombre, próximo } \\
\text { o inserto en su espacio } \\
\text { de cotidianeidad. }\end{array}$ & $\begin{array}{l}\text { Urbano, } \quad \text { periurbano } \\
\text { (vorurbano, rururbano) }\end{array}$ & $\begin{array}{l}\text { Mezcla de especies Exóti- } \\
\text { cas/adventicias con nativas } \\
\text { regionales y extrarregiona- } \\
\text { les: Escandentes. mburucu- } \\
\text { ya, campanillas, esponja } \\
\text { vegetal, . Herbáceas: llantén, } \\
\text { zurrón del pastor, diente de } \\
\text { león, pata de perdiz, rompe } \\
\text { piedra, lucera, palán palan, } \\
\text { oreja de gato, poáceas va- } \\
\text { rias, yerba de la golondrina, } \\
\text { paletaria, margarita punzó, } \\
\text { cerraja, zapallo, pimientos, } \\
\text { etc.) Distribución uniforme o } \\
\text { regular, artificial, individual o } \\
\text { en grupos. Distribución irre- } \\
\text { gular, al azar o agrupada, } \\
\text { individual o en grupos. En el } \\
\text { caso de baldíos y vertederos } \\
\text { variarán según contamina- } \\
\text { ción del suelo, por ejemplo } \\
\text { escombros y desechos de } \\
\text { edificación presencia de } \\
\text { calcáreos y carbonatos; } \\
\text { restos de comidas, desbro- } \\
\text { ces y animales muertos } \\
\text { mayor acides. }\end{array}$ & $\begin{array}{l}\text { Varía según el tamaño de la } \\
\text { fitocenosis que la aloja o con } \\
\text { la que interactúa. Insectos } \\
\text { diversos y avifauna adventi- } \\
\text { cia y nativa. En las de mayor } \\
\text { extensión: Animales exóticos } \\
\text { y/o adventicios (gorriones, } \\
\text { palomas domésticas, ratas, } \\
\text { cucarachas, etc.); domésti- } \\
\text { cos vagabundos y silvestres } \\
\text { domesticados (gatos, perros, } \\
\text { conejos, paseriformes, etc.), } \\
\text { silvestres oportunistas (pito- } \\
\text { güés, cachilos, tacuarita, } \\
\text { lechuzas, cotorras, avispas, } \\
\text { moscas y mosquitos). Si se } \\
\text { asocian a vertederos ade- } \\
\text { más de animales domésticos } \\
\text { vagabundo aparecen nativos } \\
\text { oportunistas carroñeros y } \\
\text { predadores: jotes, caran- } \\
\text { chos, zorritos, comadrejas. }\end{array}$ \\
\hline $\begin{array}{l}\text { Arvenses } \\
\text { Áreas próximas a } \\
\text { cultivos, barbechos, } \\
\text { cabeceras de chacras } \\
\text { y quintas. Plantas que } \\
\text { han evolucionado a la } \\
\text { par de los cultivos y } \\
\text { aprovechan las prácti- } \\
\text { cas que el hombre } \\
\text { realiza }\end{array}$ & $\begin{array}{l}\text { Rural, periurbano (vo- } \\
\text { rurbano, rururbano) }\end{array}$ & $\begin{array}{l}\text { Mezcla de especies Exóti- } \\
\text { cas/adventicias con nativas } \\
\text { regionales y extrarregiona- } \\
\text { les: vinculadas a los cultivos } \\
\text { y tierras de labor. Muchas de } \\
\text { ellas consideradas malezas } \\
\text { (cebollín, pasto ruso, cerraja, } \\
\text { yuyo colorado, verdolagas, } \\
\text { ortigas) }\end{array}$ & $\begin{array}{l}\text { Avifauna que aprovecha } \\
\text { frutos y semillas (cotorras, } \\
\text { palomas, pitogües, viuditas, } \\
\text { zorzales, jilgueros, cardena- } \\
\text { les). Insectos y aves vincu- } \\
\text { lados a flores y la poliniza- } \\
\text { ción (avispas, abejorros, } \\
\text { abejas, coleópteros, picaflo- } \\
\text { res). Libres, conejos, ratas. }\end{array}$ \\
\hline $\begin{array}{l}\text { Viarias o Viales } \\
\text { Autovías, rutas, calles } \\
\text { y caminos terciarios, } \\
\text { secundarios y de pene- } \\
\text { tración. con sus de- } \\
\text { pendencias y límites: } \\
\text { banquinas, zanjas, } \\
\text { cunetas, alambrados y } \\
\text { cercos }\end{array}$ & $\begin{array}{l}\text { Todos, pues los atra- } \\
\text { viesan y conectan }\end{array}$ & $\begin{array}{l}\text { Varían desde las banquinas } \\
\text { hasta los límites de los pre- } \\
\text { dios contiguos, predominan- } \\
\text { do en general herbáceas } \\
\text { exóticas o adventicias en los } \\
\text { bordes de los ejes viales, } \\
\text { p.e. sorgo de alepo, cebadi- } \\
\text { lla, trébol blanco de olor, } \\
\text { girasol, maíz, sorgo, ricino, }\end{array}$ & $\begin{array}{l}\text { Asociados a los ambientes } \\
\text { naturales aledaños y a la } \\
\text { posibilidad de alimentos } \\
\text { provenientes del tráfico } \\
\text { diario (palomas, semilleros, } \\
\text { jilgueros, tijeretas, garzas, } \\
\text { cigüeñas, caranchos, jotes o } \\
\text { buitres). Reptiles y batracios } \\
\text { vinculados a cunetas, cana- }\end{array}$ \\
\hline
\end{tabular}




\begin{tabular}{|c|c|c|c|}
\hline & & $\begin{array}{l}\text { etc. Mientras que en la traza } \\
\text { o reservas y alambrados o } \\
\text { cercos crece la proporción } \\
\text { de nativas como Poáceas } \\
\text { (paja amarilla, paja estalla- } \\
\text { dora, paja colorada, paja } \\
\text { boba), Ciperáceas, Canna- } \\
\text { ceas, Fabaceas (alguna de } \\
\text { ellas arbóreas o arbustivas: } \\
\text { Acacias y Prosopis. }\end{array}$ & $\begin{array}{l}\text { les y bajos. Las rutas se } \\
\text { transforman en trampas } \\
\text { mortales para guazunchos, } \\
\text { carpinchos, zorritos, coipos, } \\
\text { cuises, liebres, sapos, tortu- } \\
\text { gas como también para } \\
\text { muchos animales domésti- } \\
\text { cos (perros, gatos, caballos, } \\
\text { cerdos) que escapan de sus } \\
\text { hábitats normales. }\end{array}$ \\
\hline $\begin{array}{l}\text { Naturales } \\
\text { Comunidades de nati- } \\
\text { vas, vegetación y fau- } \\
\text { na original del sitio, en } \\
\text { la actualidad degrada- } \\
\text { da o menguada por el } \\
\text { avance antrópico }\end{array}$ & $\begin{array}{l}\text { Naturales (Bosques, } \\
\text { pastizales, cañadas, } \\
\text { esteros, lagunas y ríos. } \\
\text { Ecotonos de ambientes } \\
\text { naturales. }\end{array}$ & $\begin{array}{l}\text { Especies vegetales nativas, } \\
\text { típicas del bioma del Chaco } \\
\text { oriental. En la matriz natural } \\
\text { en la manchas o isletas de } \\
\text { montes altos o "fuertes" } \\
\text { (denominación local por el } \\
\text { predominio de especies ricas } \\
\text { en tanino), bosques dimáxi- } \\
\text { cos con predominio de que- } \\
\text { bracho colorado chaqueño } \\
\text { (Schinopsis balansae) y } \\
\text { quebracho blanco (Aspidos- } \\
\text { perma. quebracho-blanco) } \\
\text { con sotobosque de cardos } \\
\text { ganchos o chaguar y cardos } \\
\text { chuzas (Bromelia serra y } \\
\text { Aechmea distichantha) y } \\
\text { numerosas cactáceas, todas } \\
\text { de características xerófilas; } \\
\text { manchas que se alternan } \\
\text { formaciones sabaneras con } \\
\text { palmares de palma Carandaí } \\
\text { (Copernicia alba) y densos } \\
\text { pastizales de gramíneas del } \\
\text { género Paspalum, Andropo- } \\
\text { gon, Panicum, etc y ciperá- } \\
\text { ceas en general,-en terrenos } \\
\text { deprimidos con suelos sali- } \\
\text { nos y anegamiento estacio- } \\
\text { nal. Mientras en los esteros } \\
\text { dominan las comunidades } \\
\text { de totoras, juncos, pajas y } \\
\text { peguajós (géneros Tipha, } \\
\text { Scirpus, Panicum, Talhia } \\
\text { respectivamente) y hacia } \\
\text { terrenos más altos, en abras } \\
\text { o pampas, las gramíneas de } \\
\text { los géneros Spartina, Elyo- } \\
\text { nurus, Cynodon, Stipa, Pas- } \\
\text { palum. Chloris, Setaria, etc. } \\
\text { Asociadas a terófitas (petu- } \\
\text { nias, cleome, arvejillas), } \\
\text { criptófitas tuberosas, bulbo- } \\
\text { sas y rizomatosas (Zephy- } \\
\text { ranthes, Habranthus, Com- } \\
\text { melina, etc.) y hemicriptofitas } \\
\text { arrosetas y rampantes (Sa- } \\
\text { lanum, Helyotropum, Ering- } \\
\text { yum, Gomphrena, Glandula- } \\
\text { ria) y sufrútices (Salanum). }\end{array}$ & $\begin{array}{l}\text { Varían de acuerdo con los } \\
\text { patrones de bosque, pasti- } \\
\text { zal, esteros, palmares en } \\
\text { base a sus nichos ecológi- } \\
\text { cos y habitats propios de } \\
\text { cada especie. Muchas al ver } \\
\text { degradado o reducido su } \\
\text { habitas y recursos alimenta- } \\
\text { rios se acercan y conviven } \\
\text { con las comunidades deriva- } \\
\text { das de la impronta humana } \\
\text { (arvenses, ruderales, subur- } \\
\text { banas y viales). } \\
\text { Merece destacarse la rica } \\
\text { avifauna en general y en } \\
\text { especial la asociada a los } \\
\text { humedales, algunas de ellas } \\
\text { migratorias, por lo que son } \\
\text { necesarias las medidas de } \\
\text { preservación, tando de las } \\
\text { especies en sí como la de } \\
\text { sus hábitats (lagunas, ríos, } \\
\text { arroyos, esteros, cañadas, } \\
\text { selvas de ribera y bosques } \\
\text { hidrófilos y pastizales en } \\
\text { general). También asocia- } \\
\text { dos a estos ambientes los } \\
\text { coipos, carpinchos o capiba- } \\
\text { ras, lobitos de ríos, serpien- } \\
\text { tes, sapos y ranas. En los } \\
\text { bosques, si bien muy degra- } \\
\text { dado en algunos casos, } \\
\text { pueden alojar monos aulla- } \\
\text { dores o carayá, guazunchos, } \\
\text { cotáis, gatos onzas y monte- } \\
\text { ses, comadrejas, aguaráses, } \\
\text { zorritos, conejos tapities, } \\
\text { cuises o zoogonías, tatués, } \\
\text { ratones, murciélagos y una } \\
\text { variada avifauna con paseri- } \\
\text { formes en general (boyeros, } \\
\text { churrinches, cardenales, } \\
\text { jilgueros, horneros, calan- } \\
\text { drias, viuditas) además de } \\
\text { palomas, perdices y martine- } \\
\text { tas, tucanes, loros y coto- } \\
\text { rras, rapaces diurnas (ca- } \\
\text { ranchos, halcones, caracole- }\end{array}$ \\
\hline
\end{tabular}
TROZOOTIA... ¿BIOCENOSIS ANTROPOGÉNICAS? EL CASO DEL ÁREA METROPOLITANA DEL GRAN RESISTENCIA (A.M.G.R.), CHACO. Revista Geográfica Digital. IGUNNE. Facultad de Humanidades. UNNE. Año 11. No 22. Julio - Diciembre. 2014. ISSN 1668-5180 Resistencia, Chaco. 


\begin{tabular}{|l|l|}
\hline & $\begin{array}{l}\text { En las orillas de las lagunas } \\
\text { crecen comunidades palus- } \\
\text { tres citadas en los esteros y } \\
\text { dentro del espejo de agua, } \\
\text { hidrófilas flotantes libres y } \\
\text { arraigadas como camalotes } \\
\text { o aguapeí (Eichornia), repo- } \\
\text { llitos, heledlos, lentejas y } \\
\text { acordeones de agua (géne- } \\
\text { ros Pistia, Azolla, Lemma y } \\
\text { Salvinia respectivamente), } \\
\text { irupés o platos del agua } \\
\text { (Victoria) entre otros. Mien- } \\
\text { tras siguiendo los corredores } \\
\text { fluviales (río Negro, Arazá y } \\
\text { arroyo Ojeda) bosques ripa- } \\
\text { rios ya muy degradados con } \\
\text { especies que soportan inun- } \\
\text { daciones estacionales como } \\
\text { sauce criollo, aliso de río, } \\
\text { ceibo, ingá, ibirá pita, etc. }\end{array}$ \\
\hline
\end{tabular}

También valen aquí algunas reflexiones y recomendaciones sobre tratamiento y evaluación del crecimiento y expansión urbana, sus paisajes y biocenosis asociadas, como también los impactos y problemas ambientales resultantes. Al respecto se considera que es primordial e ineludible:

1- Justipreciar que las transformaciones del paisaje, debidas a la expansión del fenómeno urbano en el territorio y al desarrollo de la capacidad tecnológica de transformación de la naturaleza, no son nuevas, pero en las últimas décadas han alcanzado un ritmo antes desconocido, según lo expresa Busquets, Jaume (2004); quien acota que "...en la mayoría de casos, el resultado de estas transformaciones se manifiesta en la generación de paisajes estandarizados e impersonales, dando lugar al fenómeno conocido como "banalización del paisaje".

2- Conocer y darle valor a los fenómenos naturales como variables condicionantes del crecimiento urbano y de la configuración de paisajes, como también de la dinámica propia de los mismos.

3- Respetar sus ritmos y ciclos naturales para no caer en desequilibrios y acrecentar la vulnerabilidad socio ambiental, y para esta meta conocer y valorar las especies locales y sus ciclos (crecimiento, reproducción, polinización, dispersión) en la configuración de los paisajes locales. De igual forma hacerlo con especies exóticas, naturalizadas y adventicias, indagando también sus beneficios y perjuicios sobre los otros organismos, incluyendo el hombre.

4- Mantener y mejorar la biodiversidad sobre la base de un manejo ecológico favorable de las especies sobresalientes, presentes o probables en estos ambientes, para lo que sería auspicioso llevar registros de sus avances y retrocesos, posibles utilidades y desventajas, ciclos propios e incidencia en la conformación y dinámica de las biocenosis naturales, arvenses, viarias y ruderales al igual que sus correspondientes ecosistemas en el área estudiada.

5- Realizar manejos integrados de maleza, para producir sustituciones de especies difíciles de controlar por otras menos problemáticas o bien reducir la densidad de éstas a niveles que no causen daño. Estas intervenciones deberán basarse en el coTROZOOTIA... ¿BIOCENOSIS ANTROPOGÉNICAS? EL CASO DEL ÁREA METROPOLITANA DEL GRAN RESISTENCIA (A.M.G.R.), CHACO. Revista Geográfica Digital. IGUNNE. Facultad de Humanidades. UNNE. Año 11. № 22. Julio - Diciembre. 2014. ISSN 1668-5180 Resistencia, Chaco. 
nocimiento biológico y ecológico de las especies implicadas y en las alteraciones micro ambientales que puedan suscitar.

6- Valorar la trascendencia de los bordes urbanos como ambientes ricos y diversos, que comprenden hábitats forestales, espacios abiertos, humedales, caminos y diferentes ámbitos antropizados con su propia dinámica local que inciden en el equilibrio de todo el conjunto espacial.

7- Revalorizar y remarcar procesos, etapas y ciclos evolutivos, tanto en lo natural como en lo antrópico, del sitio y la situación del centro urbano estudiado, para explicar el dinamismo de éste y su estado actual y prever situaciones futuras.

8- Registrar y valorar la riqueza paisajística, tanto natural como cultural para su preservación consensuada y reglamentada. 


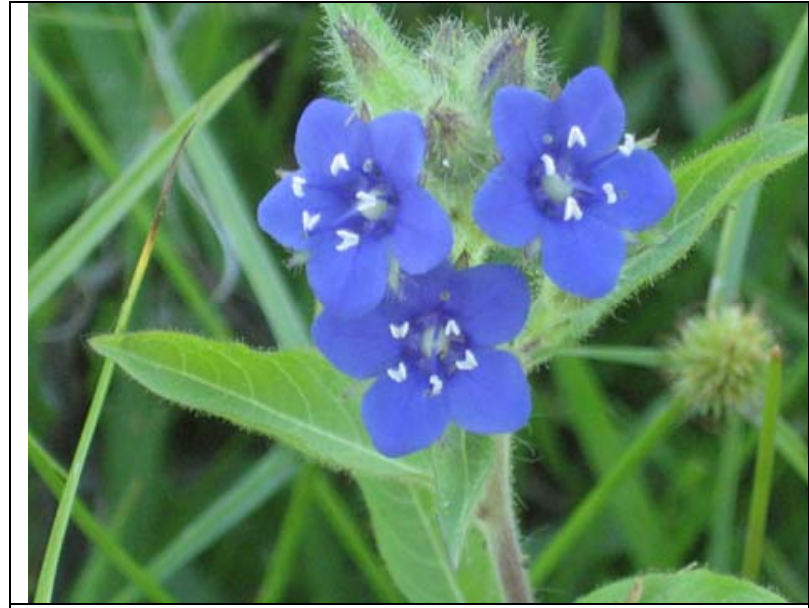

Hydrolea elatior - Terrenos húmedos, bajos, soleados. Ideal para Jardines acuáticos

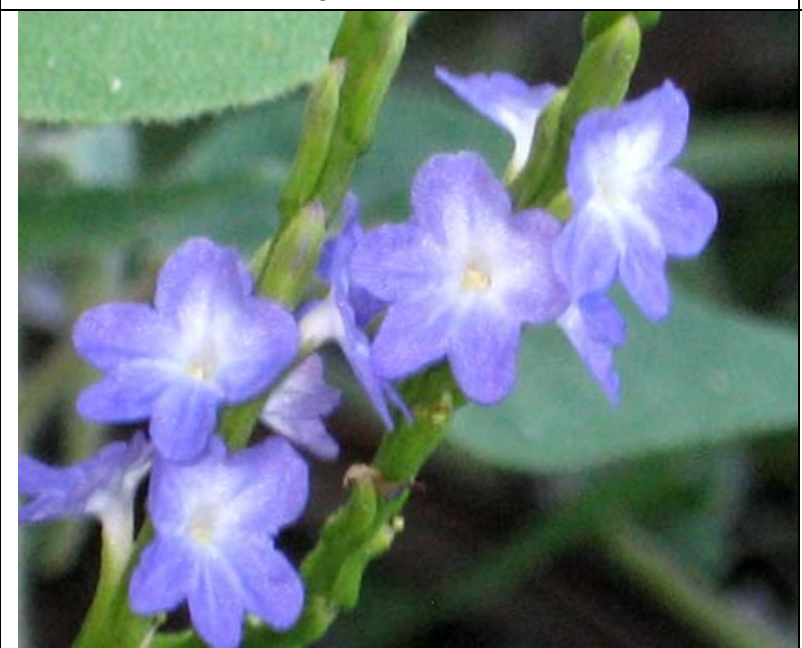

Stachytarpheta cayennensis (Rach.) Vall. Sufrútice. Terrenos húmedos, sombreados o media sombra.

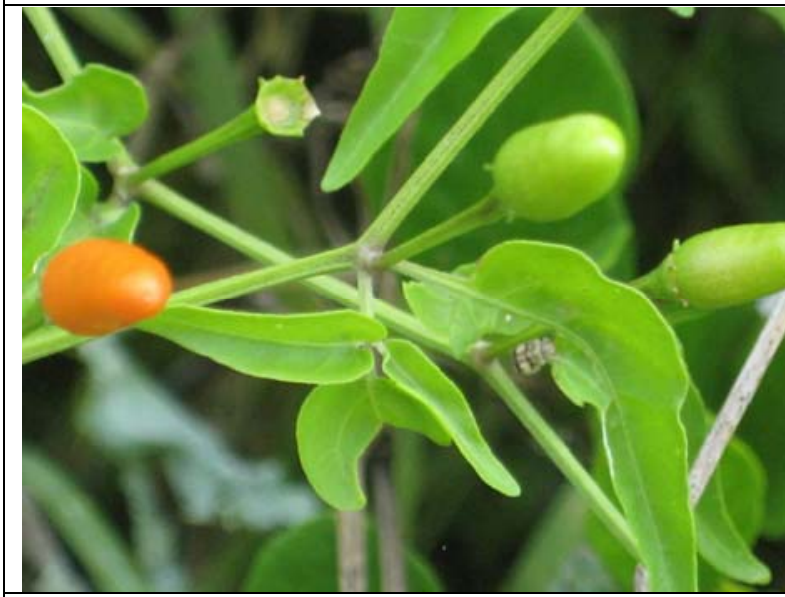

Ají cumbarí o de la mala palabra. Ornamental. Culinaria -condimento muy picante- (Capsicum chacoense)

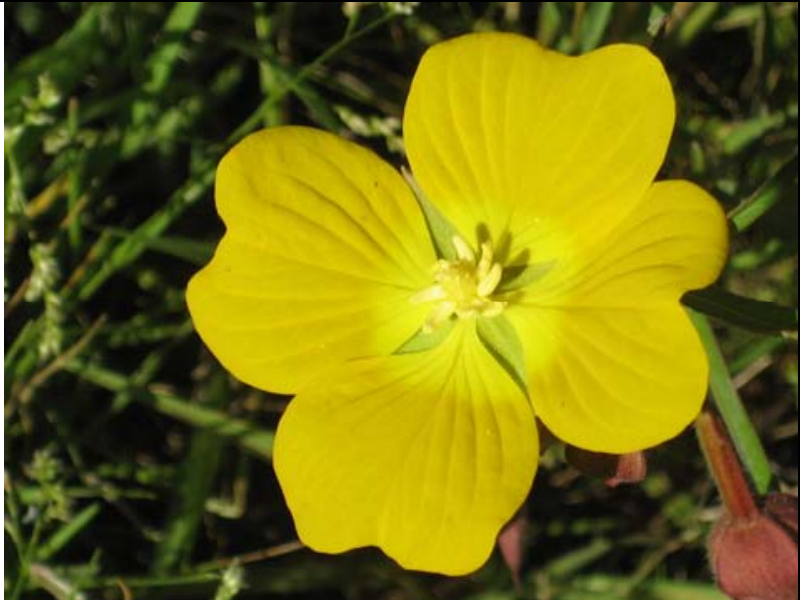

Duraznillo de agua (Ludwigia elegans). Terrenos húmedos, bajos, soleados. Jardines acuáticos

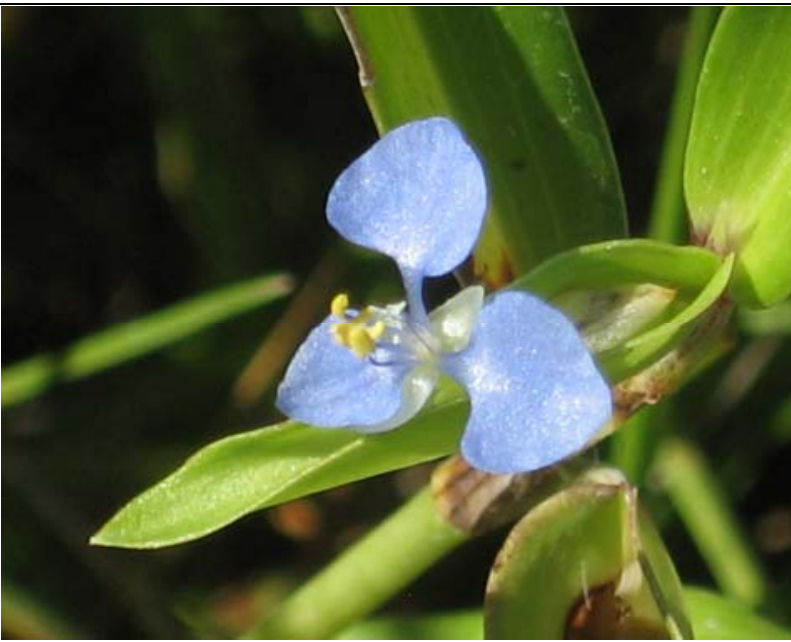

Santa Lucía (Commelina difusa). Hierba. Terrenos húmedos, bajos, soleados

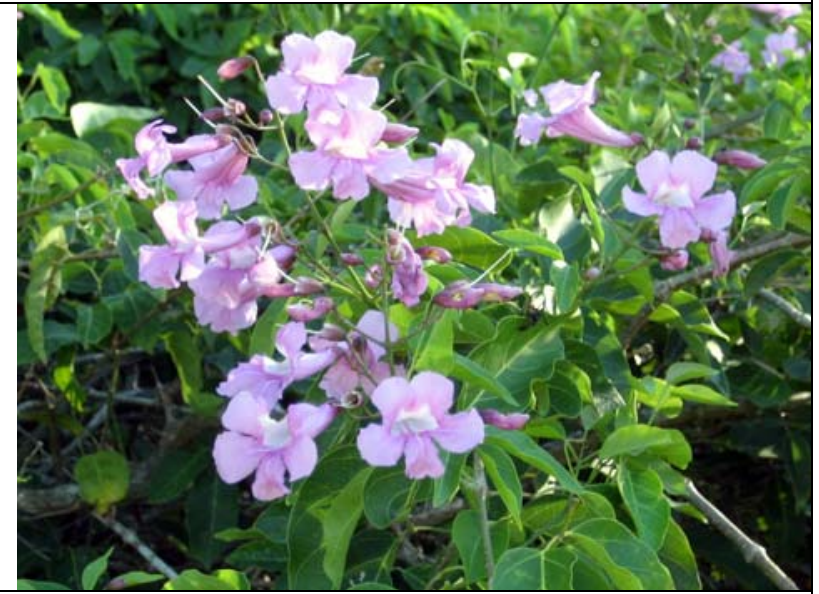

Dama de monte (Clytostoma callistegioides (Cham) Bur.) Escandente. Muros, cerco y pérgolas soleadas

Fig. 8: Especies nativas de ámbitos periurbanos de interés ornamental

Publicado en formato digital: Prof. Juan Antonio Alberto. EXPANSIÓN URBANA, PARANTROFITIA Y PARANTROZOOTIA... ¿BIOCENOSIS ANTROPOGÉNICAS? EL CASO DEL ÁREA METROPOLITANA DEL GRAN RESISTENCIA (A.M.G.R.), CHACO. Revista Geográfica Digital. IGUNNE. Facultad de Humanidades. UNNE. Año 11. No 22. Julio - Diciembre. 2014. ISSN 1668-5180 Resistencia, Chaco.

En: http://hum.unne.edu.ar/revistas/geoweb/default.htm 

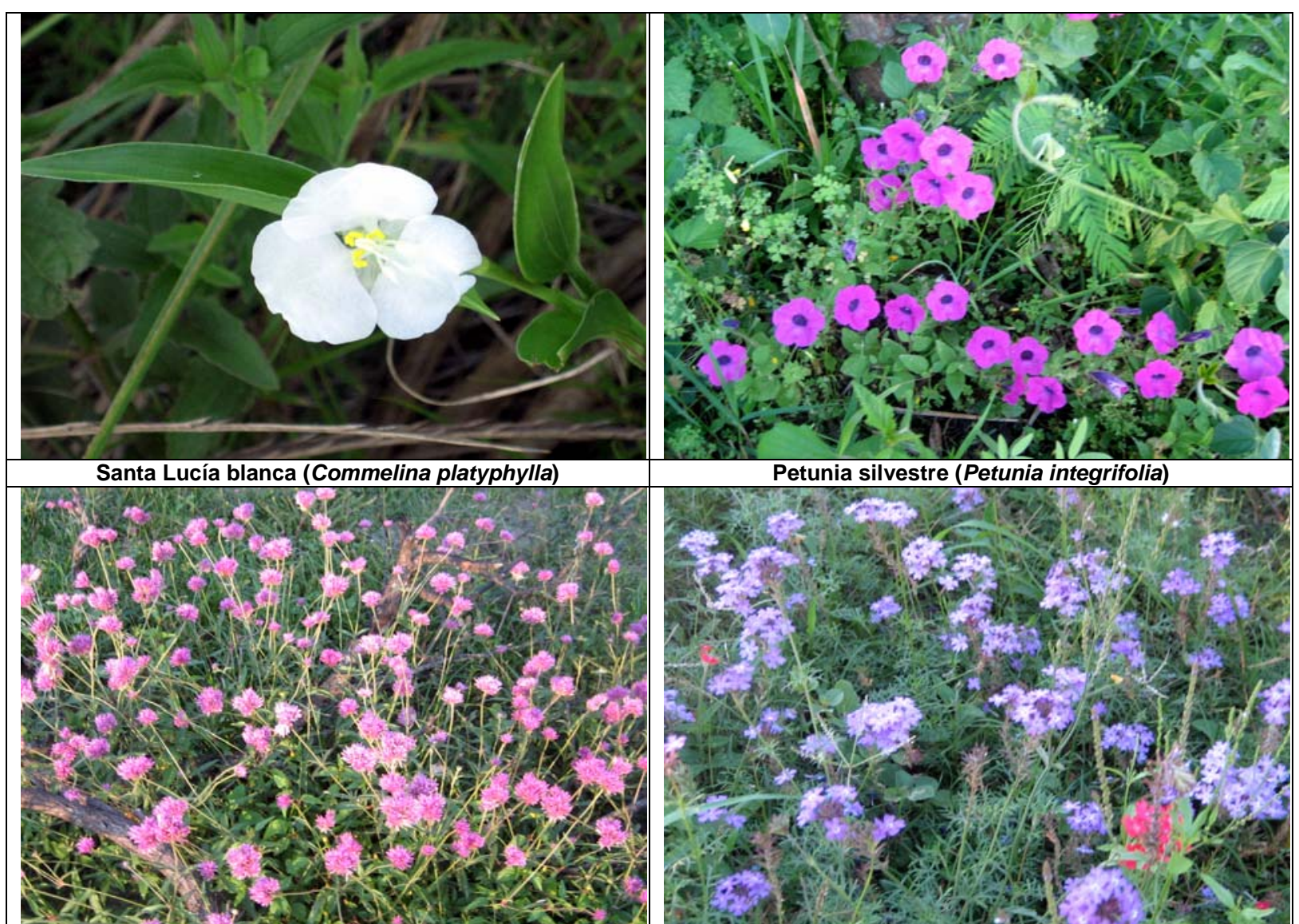

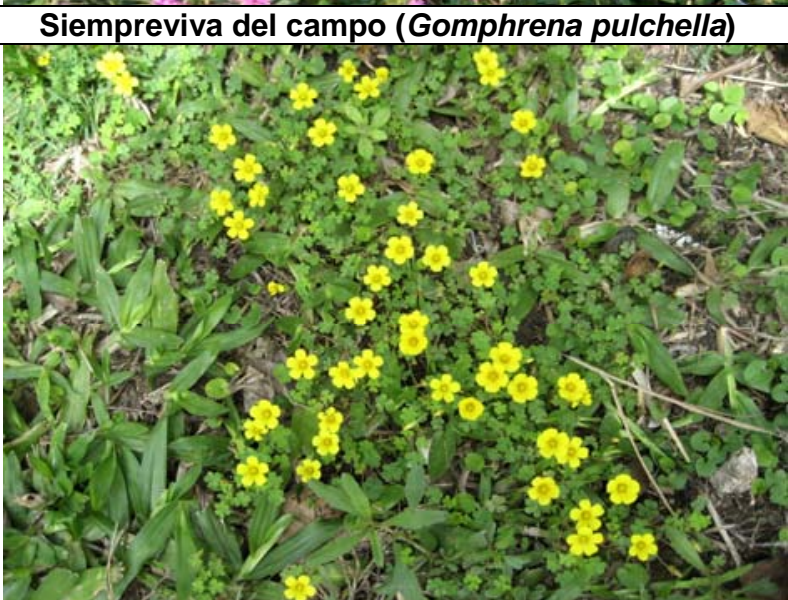

Trébol o vinagrillo (Oxalis). Herbácea, tapiz vegetal

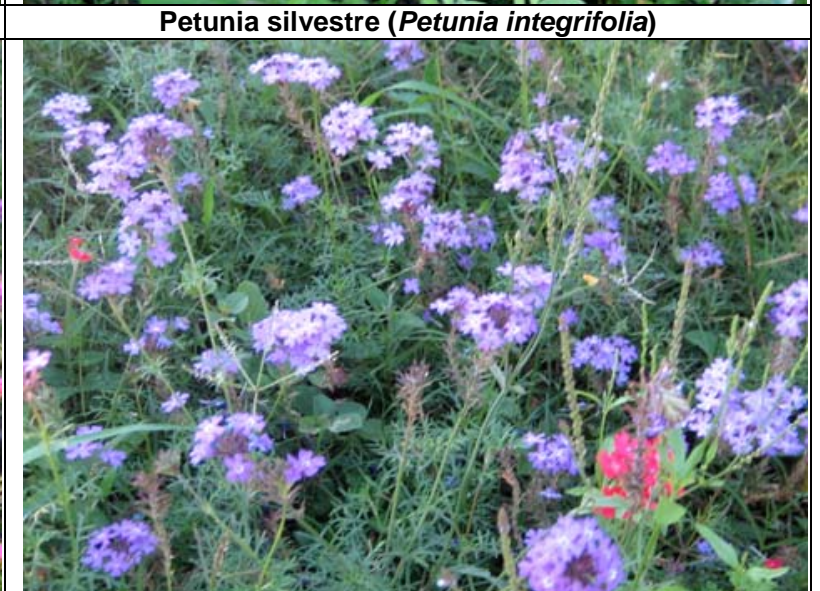

Té de burro, Verbena azul (Glandularia pulchella)

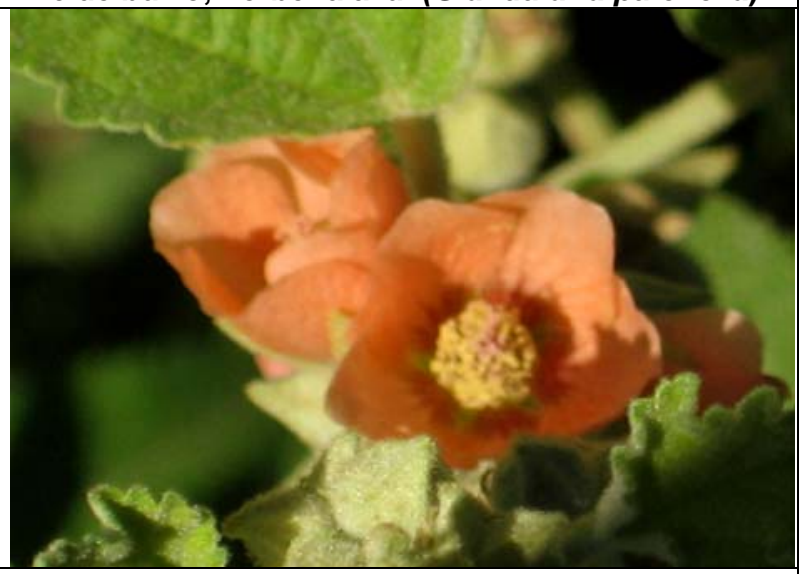

Malvavisco (Sphaeralcea bonariensis). Subarbusto

Fig. 9: Especies nativas de ámbitos periurbanos de interés ornamental

Publicado en formato digital: Prof. Juan Antonio Alberto. EXPANSIÓN URBANA, PARANTROFITIA Y PARANTROZOOTIA... ¿BIOCENOSIS ANTROPOGÉNICAS? EL CASO DEL ÁREA METROPOLITANA DEL GRAN RESISTENCIA (A.M.G.R.), CHACO. Revista Geográfica Digital. IGUNNE. Facultad de Humanidades. UNNE. Año 11. No 22. Julio - Diciembre. 2014. ISSN 1668-5180 Resistencia, Chaco.

En: http://hum.unne.edu.ar/revistas/geoweb/default.htm 


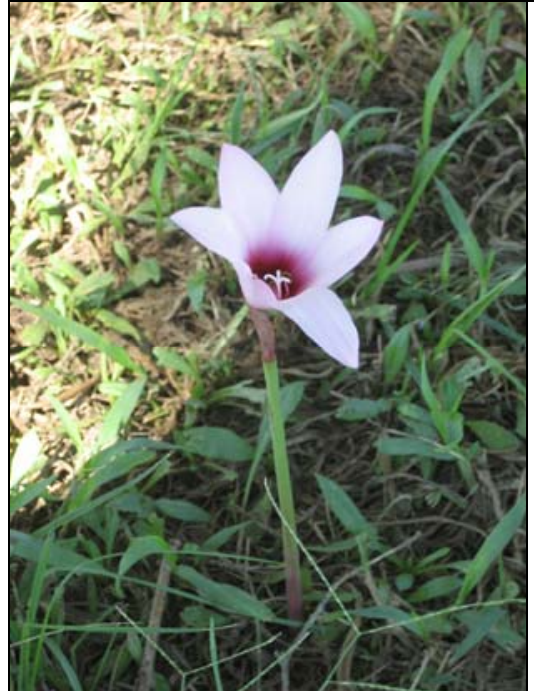

Habrantus. Herbácea. Bulbosa.

Suelos francos. Soleados, Con mayor frecuencia en comunidades arvenses y ruderales

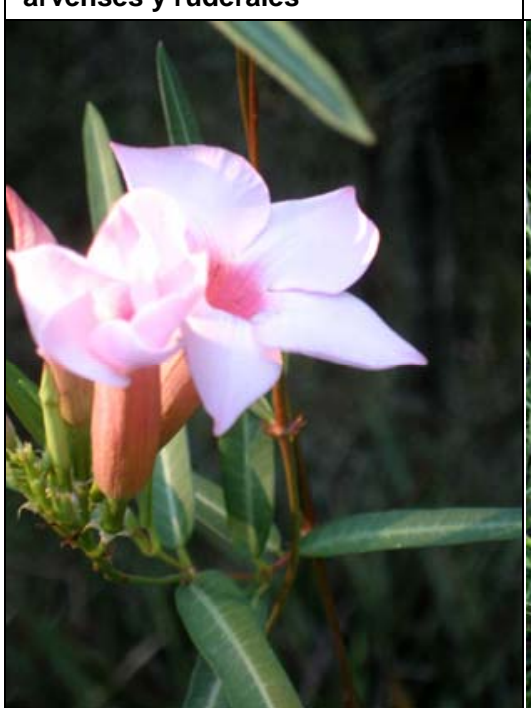

Rhabdadenia ragonesei Wood. Escandente. Media sambra

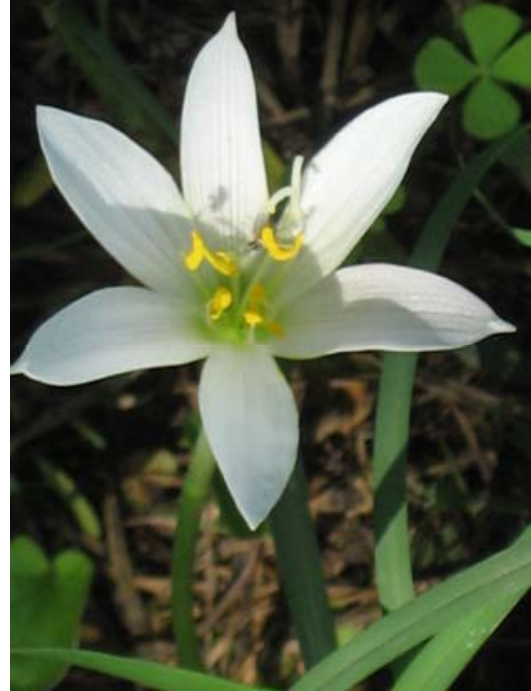

Azucenita de campo. Zephyranthes candida. Herbácea. Bulbosa. Suelos francos, húmedos. Soleados y media sombra

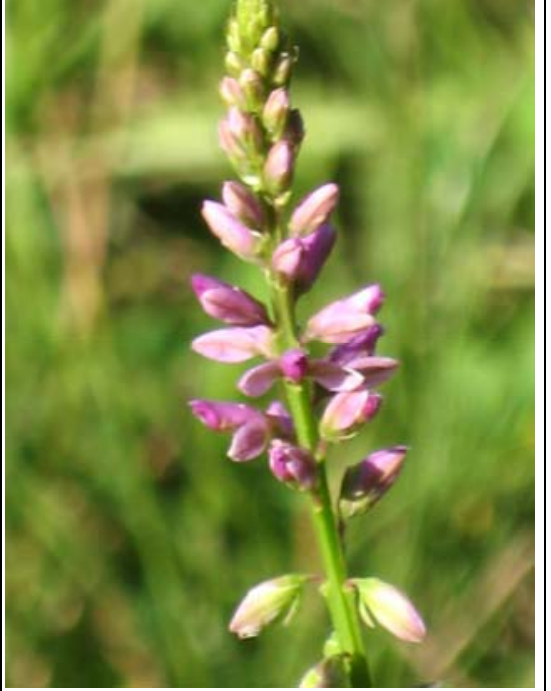

Polygala molluginifolia. Herbácea. Macetas y terrenos bien drenados, soleados

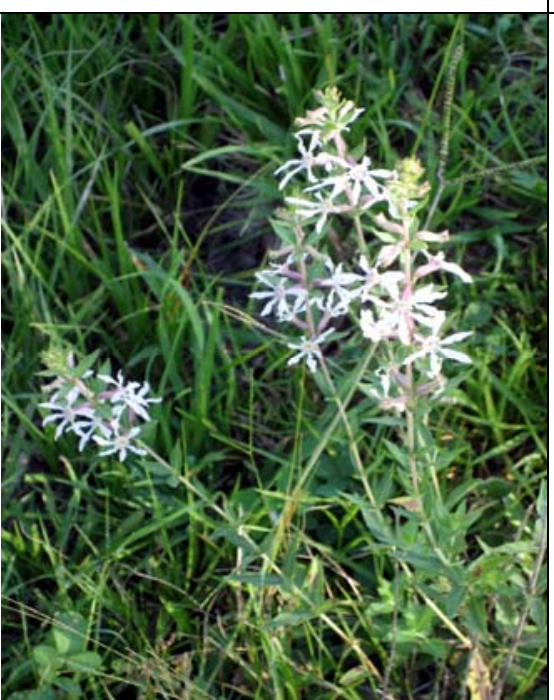

Siete sangrías, sanguinaria (Cuphea fruticosa Spreng.) Ambientes soleados

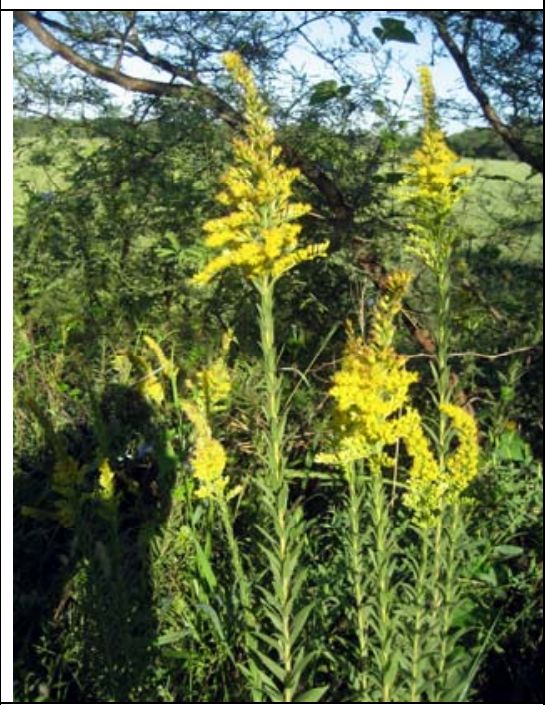

Vara dorada (Solidago chilensis) Ambientes soleados.

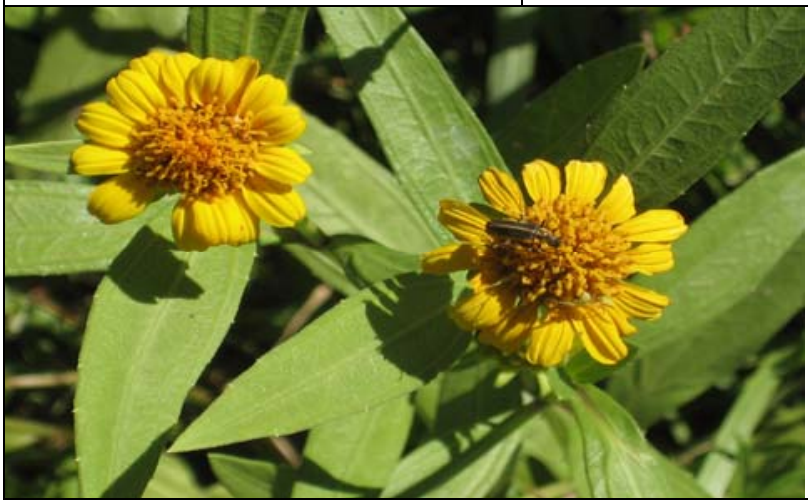

Sunchillo (Wedelia glauca). Terrenos húmedos

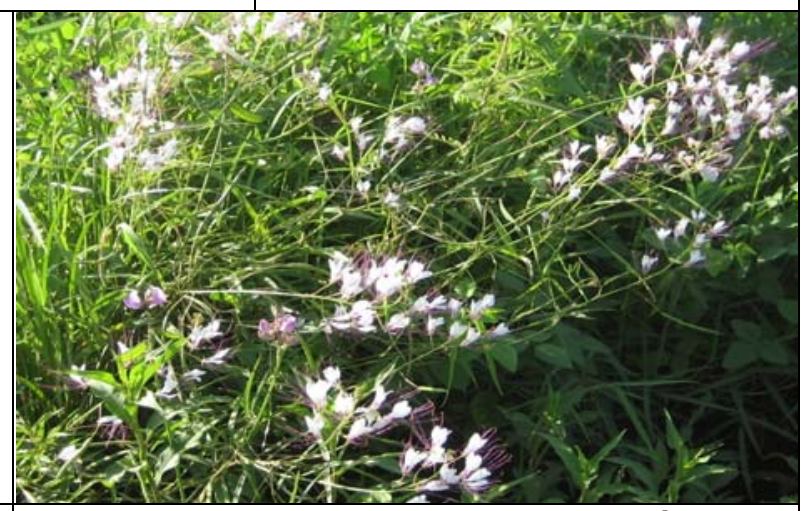

Cleome (Cleome hassleriana). Terrenos húmedos

Fig. 10: Especies nativas de ámbitos periurbanos de interés ornamental

Publicado en formato digital: Prof. Juan Antonio Alberto. EXPANSIÓN URBANA, PARANTROFITIA Y PARANTROZOOTIA... ¿BIOCENOSIS ANTROPOGÉNICAS? EL CASO DEL ÁREA METROPOLITANA DEL GRAN RESISTENCIA (A.M.G.R.), CHACO. Revista Geográfica Digital. IGUNNE. Facultad de Humanidades. UNNE. Año 11. № 22. Julio - Diciembre. 2014. ISSN 1668-5180 Resistencia, Chaco.

En: http://hum.unne.edu.ar/revistas/geoweb/default.htm 
Revista Geográfica Digital. IGUNNE. Facultad de Humanidades. UNNE. Año 11. № 22.

Julio - Diciembre 2014. ISSN 1668-5180 Resistencia, Chaco

\section{Bibliografía}

- Acha, Pedro N. y Szyfres, Boris (2001) Zoonosis y enfermedades transmisibles comunes al hombre y a los animales. Organización Panamericana de la Salud. Washington, D.C.: 3.a ed Volumen I. Bacteriosis y Micosis.

- Alberto, Juan Antonio (2012). Las Fronteras Urbanas. Escenarios de Transición, Vulnerabilidad y Conflictos En el Área Metropolitana del Gran Resistencia. Cap. V. Los Escenarios Ambientales Urbano. Pp. 64 a 95. En: Escenarios Vulnerables del Nordeste Argentino. Ana María Foschiati (Coordinadora). Ed. EUDENE. Corrientes, Argentina.

- Alberto, Juan Antonio (2013). Expansión Urbana, Paisajes y Sustentabilidad Ambiental. El Caso del Área Metropolitana del Gran Resistencia. En: $5^{\circ}$ Seminario sobre Políticas Urbanas, Gestión Territorial y Ambiental para el Desarrollo Local. FAU - IPUR-BAT. UNNE. 6 y 7 de junio de 2013. Resistencia. Chaco. 2013. ISSN 1851-3506

- Balu, Hélène, et al. (2014). Charte pour la Biodiversité Urbaine. Le Territoire de Marseille. Agam - Agence d'Urbanisme de l'Agglomération Marsellaise. Marseille. Février 2014.

- Busquets, Jaume (2004). El Paisaje como Oportunidad. En Portada. CEIDA. Centros de Educación e Investigación Didáctico Ambiental. En:

http://www.euskadi.net/vima_educacion/indice_c.htm

- Chiesura, Anna (2010). Verso una gestione ecosistemica delle aree verdi urbane e peri-urbane Analisi e proponte. Rapporti 118/2010. Istituto Superiore per la Protezione e la Ricerca Ambientale (ISPRA). ISBN 978-88-448-0386-5. Roma

- Centro Mario Molina para Estudios Estratégicos sobre Energía y Medio Ambiente (2013). Reforma Urbana. 100 Ideas para las Ciudades de México. México D.F. (Consultada 12/06/2014). En: http://centromariomolina.org/desarrollo-sustentable/temas/reforma-urbana-100-ideas-para-lasciudades-mexicanas/

http://centromariomolina.org/wp-

content/uploads/2013/10/ReformaUrbana100IdeasparalasCiudadesdeMexico.pdf

- Conseil Général du Val-de-Marne (2008). Guide des bonnes pratiques pour la protection et la gestión des lisières en milieu urbanicé. Nature et ville : le défi du Val-de-Marne. L'arc boisé-Charte forestière. Conseil général du Val-de-Marne, Direction des Espaces Verts et du Paisaje y Direction de la Communication. Paris.

- da Costa Moreira, Henrique José y Nippes Bragança, Horlandezan Belirdes (2011). Manual de Identificação de Plantas Infestantes: Hortifrúti. Campinas, São Paulo: FMC Agricultural Products.

- da Costa Moreira, Henrique José y Nippes Bragança, Horlandezan Belirdes (2010). Manual de Identificação de Plantas Infestantes: Arroz. Campinas, São Paulo: FMC Agricultural Products.

- da Costa Moreira, Henrique José y Nippes Bragança, Horlandezan Belirdes (2010). Manual de Identificação de Plantas Infestantes: Cultivos de Verão. Campinas, São Paulo: FMC Agricultural Products.

- Dana, Elías D. 2003. Malherbología. Tema 1.- Página de Malherbología 2002-2003. Universidad de Almería. Página Web: http://www.ual.es/personal/edana/bot.

- do Lago Paiva, Celso; Fonseca Santos, Ana Carla (2006). Taperas e Suas Plantas: Etnobotânica dos Antigos Assentamentos Humanos. En: Dialogos - Revista do Departamento de Historia e do Programa de Pós-Graduação em História, Universidade Estadual de Maringá. Maringá, Brasil. vol. 10, núm. 3, 2006, pp. 33-53

- Faggi, A.; Prepelizin, P. (2006). Riqueza de aves a lo largo de un gradiente de urbanización en la ciudad de Buenos Aires. Revista Museo Argentino de Ciencias Naturales Bernardino Rivadavia 8(2): pp. 289-297.

Publicado en formato digital: Prof. Juan Antonio Alberto. EXPANSIÓN URBANA, PARANTROFITIA Y PARANTROZOOTIA... ¿BIOCENOSIS ANTROPOGÉNICAS? EL CASO DEL ÁREA METROPOLITANA DEL GRAN RESISTENCIA (A.M.G.R.), CHACO. Revista Geográfica Digital. IGUNNE. Facultad de Humanidades. UNNE. Año 11. No 22. Julio - Diciembre. 2014. ISSN 1668-5180 Resistencia, Chaco.

En: http://hum.unne.edu.ar/revistas/geoweb/default.htm 
- Garcia-Abad Alonso, Juan Javier (1995). Biogeografía urbana: presentación del caso de Alcalá de Henares. Anales de Geografía de la Universidad Complutense, $n^{\circ} 15,315-323$. Servicio de Publicaciones. Universidad Complutense. Madrid.

- Gioanetto, Fulvio; Díaz Vilchis, José Trinidad y Quintero Sánchez, Rubén. (2010). Manual de utilización de las malezas silvestres de Michoacán. Usos allelopáticos, agroecológicos, medicinales, alimentarios, veterinarios y rituales de las adventicias silvestres y arvenses. Centro de Agronegocios de Michoacán. Morelia. Mich. México

- Huguet del Villar, E. (1929): Geobotánica. Ed. Labor. Barcelona.

- Klaus, Gregor (2003). Ville et nature: y a-t-il vraiment incompatibilité? En: HOTSPOT. Dossier Biodiversité: en Milieu Urbain. Dialogue entree Recherche et Pratique. Bulletin d'information du Forum Biodiversité Suisse. № 8, octobre 2003, pag. 3. Forum Biodiversité Suisse, ASSN, Berne, En: www.biodiversity.ch

- Kuhlmann, M.; Kühn, E. (1947). A flora do Distrito de Ibiti (ex-Monte Alegre), município de Amparo. I - Inventário florístico. II - Subsídios para estudo da biocenose regional. São Paulo: Instituto de Botânica, 221 p.

- La Grotteria, Jorge (2014) Registros Ecológicos de la Comunidad. Ecoregistros. En. http://ecoregistros.com.ar/site/index.php

http://www.ecoregistros.com.ar/site/revista.php http://aves-argentina.blogspot.com.ar/search?q=cachilo

- Lowe S., Browne M., Boudjelas S., De Poorter M. (2004) 100 de las Especies Exóticas Invasoras más dañinas del mundo. Selección del Global Invasive Species Database. Grupo Especialista de Especies Invasoras (GEEI), Comisión de Supervivencia de Especies (CSE) de la Unión Mundial para la Naturaleza (UICN), 12pp. Versión traducida y actualizada. Auckland. Nueva Zelanda: Noviembre 2004.

- Maestre, Fernando y Escudero, Adrián (2008). Introducción. Cap. 1. En: "Introducción al análisis espacial de datos en ecología y ciencias ambientales: Métodos y Aplicaciones". ISBN: 978-849849-308-5, 849 pp., Dykinson S.L., Madrid, España.

- Marín, Nidia (2014). Expansión urbana es fragmentada, desproporcionada, y no planificada. OEME en Línea. Organización Editorial Mexicana. (Consultada 11/06/2014) En: http://www.oem.com.mx/oem/notas/n3341955.htm

- Marino, Gustavo D. y Parera, Aníbal F -Coordinadores. (2012). Guía de Bolsillo para Aves y Plantas de los Pastizales Naturales del Cono sur de América del Sur. Argentina, Brasil, Paraguay y Uruguay. 50 especies de plantas silvestres de las pampas. Alianza del Pastizal. ISBN 978-987-33-1218-2. Buenos Aires.

- Morello, Jorge y Matteucci, S.D. (2001). Apropiación de ecosistemas por el crecimiento urbano. Gerencia Ambiental Año 8 № 76. Pp: 483-502, 522-527.

- Olivencia Ortega, Ana y Robles Cruz, Ana Belén Morales. Torres, Ma. Concepción (Directora) (1983). Las Plantas Adventicias como Bioindicadoras en la Zona Litoral Almeriense. Extracto del trabajo titulado «Estudio botánico de las plantas adventicias en los cultivos extratempranos del litoral alménense» Departamento de Botánica de la Facultad de Ciencias de la Universidad de Granada. Granada.

- Orros, Melanie E.; Thomas, Rebecca L.; Holloway, Graham J. y Fellowes, Mark D. E. (2014). Supplementary feeding of wild birds indirectly affects ground beetle populations in suburban gardens. Urban Ecosyst DOI 10.1007/s11252-014-0404-x. School of Biological Sciences, University of Reading, UK. Published online: 22 August 2014. Springer. En: https://www.academia.edu/t/MtEaz/8086686/Supplementary_feeding_of_wild_birds_indirectly_affe cts_ground_beetle_populations_in_suburban_gardens TROZOOTIA... ¿BIOCENOSIS ANTROPOGÉNICAS? EL CASO DEL ÁREA METROPOLITANA DEL GRAN RESISTENCIA (A.M.G.R.), CHACO. Revista Geográfica Digital. IGUNNE. Facultad de Humanidades. UNNE. Año 11. № 22. Julio - Diciembre. 2014. ISSN 1668-5180 Resistencia, Chaco.

En: http://hum.unne.edu.ar/revistas/geoweb/default.htm 
- Real Jiménez, Raimundo (2009). La ciudad y la biodiversidad urbana. OMAU (Observatorio del Medioambiente Urbano). Málaga

- Rivas-Martínez, Salvador (2007). Mapa de series, geoseries y geopermaseries de vegetación de España. [Memoria del Mapa de Vegetación Potencial de España]. En ITINERAGEOBOTANICA (Nueva Serie). Parte I. Volumen 17. Asociacion Española de Fitosociologia (AEFA) y Federation Internationale de Phytosociologie (FIP)

- Sierra Vásquez, Marcela Alejandra (2012). Ciudad y Fauna Urbana. Un estudio de caso orientado al reconocimiento de la relación hombre, fauna y hábitat urbano en Medellín. Tesis de Grado. Escuela de Planeación Urbano- Regional. Facultad de Arquitectura. Universidad Nacional de Colombia, sede Medellín.

- Terrisse, Jean - Redactor (2012). Terrains piétinés et rudéraux. Poitou-Charentes Nature. En: http://www.poitou-charentes-nature.asso.fr/-Terrains-pietines-et-ruderaux-.html

- Urzúa Soria, Fernando. (2012) Principios del Manejo Integrado de Malezas. Dpto. de Parasitología Agrícola. Universidad Autónoma Chapingo. En: www.senasica.gob.mx/includes/asp/download.asp

- Vilà M., Bacher S., Hulme P., Kenis M., Kobelt M., Nentwig W., Sol D., Solarz W. 2006. Impactos ecológicos de las invasiones de plantas y vertebrados terrestres en Europa. Ecosistemas. 2006/2. En: (URL: http://www.revistaecosistemas.net/articulo.asp?ld=425\&ld_Categoria=2\&tipo=portada). 